\title{
An Overview of Calcite Recovery by Flotation
}

\author{
Priyanka Dhar $^{1}$ (D) $\cdot$ Maria Thornhill ${ }^{1} \cdot$ Hanumantha Rao Kota ${ }^{1}$ (D)
}

Received: 13 April 2020 / Revised: 28 July 2020 / Accepted: 30 July 2020 / Published online: 23 September 2020

(C) The Author(s) 2020

\begin{abstract}
In general, precipitated calcium carbonate ( $\mathrm{PCC})$ is used as a mineral filler in paper industries; while natural calcite $\left(\mathrm{CaCO}_{3}\right)$ ore is also suitable for industrial use if it is a finely ground high-grade material. Naturally, calcite is found in the form of high- or low-grade ores and it is one of the most widely distributed industrial minerals on the earth's crust. However, it is rarely found in its pure form and is generally associated with other gangue minerals; the type and percentage of which vary from one deposit to another. These minerals are generally separated by flotation and/or magnetic separation (in the case of iron impurities). Calcite ores typically contain metal sulphide, silicate, or other calcium-containing impurity minerals, which can be removed by flotation. A tremendous amount of research has been performed on refining the flotation process for calcite ores and designing the reagents (specifically, collectors) to increase the efficiency of the process. Metal sulphide/silicate impurity minerals can be removed by the froth-flotation process using amines and xanthate collectors. Alternatively, fatty acids are used as collectors to float calcium-type minerals directly from the ore. This paper reviews the industrial practices and fundamental research related to collectors surrounding calcite ore flotation. This article presents and reviews collectors for the beneficiation of high-grade calcite ores which have been reported in the literature in order to assist judicial choice of collecting agents in flotation.
\end{abstract}

Keywords Calcite $\cdot$ Zeta potential $\cdot$ Adsorption $\cdot$ Flotation $\cdot$ Cationic reagents

\section{Introduction}

Calcite is one of the most abundant simple salts in the earth's surface and in sedimentary rocks; it occurs in the form of armours and skeletal frames of marine creatures. It is the prime constituent of limestone, chalk etc. In igneous rocks, calcites are present in the form of fine-to-coarse grains. Carbonatites, kimberlites, and lamprophyres are some of the alkaline igneous rocks, which contain more than $50 \%$ of carbonates, especially calcites (Chang et al. 1996). It is therefore said that calcite is one of the most abundant simple carbonate salts on the earth's surface as it is found in almost all kinds of rock samples. The most important carbonate minerals belonging to the calcite group include magnesite, rhodochrosite, siderite, and smithsonite.

Calcite has the chemical formula $\mathrm{CaCO}_{3}$, and the chemical structure is shown in Fig. 1. To be specific, calcite is composed

Priyanka Dhar

priyanka.dhar@ntnu.no

1 Department of Geoscience and Petroleum, Norwegian University of Science and Technology (NTNU), S.P. Andersens veg 15a, 7031 Trondheim, Norway of a basic structure of one atom of calcium, one atom of carbon and three atoms of oxygen. Calcite is colourless or white when pure but may contain any colour, i.e. red, pink, yellow, green, blue, lavender, black, or brown, which owing to the presence of diverse impurities. Thus, it implies calcite may be transparent, translucent, or opaque. Its lustre ranges from vitreous to dull; many crystals, especially the colourless ones, are vitreous, whereas granular masses, especially those that are fine-grained, tend to be dull. Additionally, the specific gravity of calcite is approximately 2.71 .

The three important crystal occurrences (distinctive shapes of the mineral) of calcite are (1) prismatic (both short and long), (2) rhombohedral, and (3) scalenohedral. Twinning is a common property in crystalline limestones. Some calcites fluoresce under ultraviolet light; some are also triboluminescent (luminescent when scratched); and some other samples of calcite show birefringence (Dietrich 2013).

Regarding applications of these calcium-containing minerals, calcium carbonate, silica, wollastonite, kaolin, and talc, etc. are used as fillers in various industrial sectors with specific quality requirements and cost. Calcite is a valuable industrial mineral used in the production of value-added products such as paper, polymers, steel, and paint. The calcite quality requirements for these industries are presented below. 


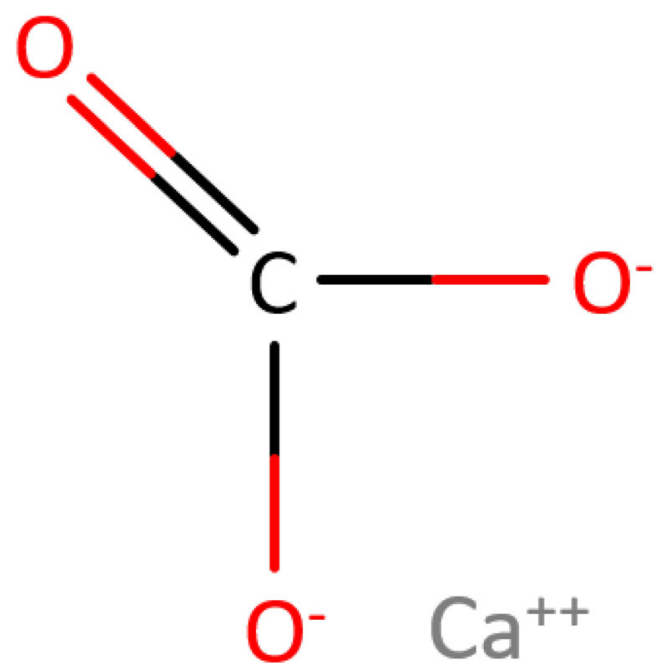

Fig. 1 Chemical structure of calcite (redrawn from Pubchem 1977)

The Paper Industry Precipitated or beneficiated calcium carbonate is widely used as a filler and coating material in the manufacture of paper. For coating applications, the desired product should have a brightness of 93 to $95 \%$. An Einlehner abrasiveness number in the range of 18 to 23 is required for use as a filler and for coating purposes. The acid-insoluble content should be below $0.5 \mathrm{wt} \%$ to be commercially acceptable. Paper production requires calcite possessing as uniform particle size distribution as is possible. A minimum of $75 \mathrm{wt} \%$ of the particles should have an equivalent spherical diameter of less than $1 \mu \mathrm{m}$ or $5 \mu \mathrm{m}$, for coating and filler purposes, respectively. This prerequisite emphasizes the importance of fine-grinding techniques for successful utilization of calcite in the paper market.

Polymer Composites Minerals are used as fillers in polyolefinic composites. They are added to a polymer matrix to improve the properties of the host polymer such as stiffness, opacity, environmental stability, gas permeability, and electrical conductivity. Calcium carbonate is the most widely used filler for thermoplastics and composite materials. In mineral-filled polymer composites, it is important to disperse particles individually in the matrix. Separation of particles from aggregates and promoting the wetting of particles by the polymer are the most important factors. This is achieved by matching the calcite surface properties to those of the matrix into which the dispersion is to take place. Stearic acid or calcium stearate is commonly used for surface modification of calcium carbonate.

Paint Industry Calcium carbonate is the most widely used extender pigment by the surface coating industry; other large users are the rubber and plastic industries. It is used throughout the range of water- and solvent-based paints for interior and exterior applications. The properties exhibited vary with the type of extender used and depend on individual physical characteristics and, in the case of naturally occurring grades, on the crystal form of the minerals from which they are derived, the presence of impurities, and the degree of refinement. The pigment particles' crystal form, size, shape, and size distribution affect the pigment's film-packing properties; oil absorption; film strength and permeability; and surface texture as well as the dispersion, settling, and rheology characteristics.

The Steel Industry Iron ore pellets are stable and homogenous and therefore easy to transport and load into the blast furnace. Limestone (both low and high grade) and lime are employed in the preparation of these iron ore pellets. An alternative raw material for the blast furnace is iron ore sinter. Limestone and lime added to the sinter react with impurities and balance the slag composition of pig iron production.

Calcite occurs in nature either as high-grade (with $>75 \%$ calcite) or low-grade calcite ores (with $<30 \%$ calcite). Generally other carbonate, phosphate, silicate, and iron sulphide minerals are associated with the calcite ores. Gravity and/or magnetic separation and flotation are the beneficiation techniques most commonly applied to calcite ores. However, flotation is the most effective solution in industries, both technologically and economically, when upgrading calcite ores. The reasons are (1) flotation is highly efficient as compared with the physical separation processes. (2) Magnetic separation proved potential for removal of iron sulphide impurities; however, cases, the iron sulphide grains are deeply disseminated within the calcite matrix, cases, magnetic separation may not be employed as the sole separation process.

Flotation is primarily based on differences in physicochemical properties of the minerals. Surface properties play an important role in establishing the electrical characteristics of interfaces. Every pure mineral in water carries a certain surface charge due to hydroxylation or protonation of surface ions based on the $\mathrm{pH}$ of the solution. In flotation, specific reagents, i.e. collectors, activators, depressants, modifiers, frothers, etc., are employed in order to alter the surface properties of minerals in an aerated slurry. If the desired mineral is not naturally hydrophobic, it is essential to modify its surface properties in order that it becomes hydrophobic and will report to the float fraction, separating it from gangue waste minerals (unless reverse flotation is required, in which case gangue waste minerals report to the float fraction).

The charged surface ions of a particle and the oppositely charged counter-ions diffused into the bulk of the solution constitute an electric double layer. The value of the electric potential at the shear plane of the particle when it is moving in an applied electric field is termed as zeta potential. There are 
various ways of calculating the zeta potential such as electrophoresis, dispersion method, streaming potential method, electroosmosis, and sedimentation potential method. Electrophoresis is most frequently used in studies related to minerals (Leja 1982; Douglas and Walker 1950). Numerous papers were published defining the calcite surface charge considering the electrolyte concentration, experimental conditions, the origin of materials, and the various ions of solution (Quast 2016).

With respect to flotation, the adsorption mechanism of the reagent on the calcite mineral was studied by using different techniques such as FTIR (Fourier transform infrared), UV (ultraviolet), and XPS (X-ray photoelectron spectroscopy). Generally, the interaction is due to electrostatic, physisorption, chemisorption, ion exchange, or surface precipitation methods; however, it can also occur because of indirect activation processes (Leja 1982). The adsorption of various reagents at calcite and impurity mineral surfaces is reviewed in this paper since different mechanisms are reported in the literature to explain adsorption phenomena.

Reagent selection plays an important role in the flotation processes. The different reagent systems used can be classified into two fields: (1) cationic reagents, when calcite was the major component and the impurity (gangue) minerals were floated, and (2) anionic reagents, when calcite occurred in moderate quantities in the ore and was being directly floated. The development in molecular structures of reagents led to a comprehensive understanding in the expansion in selection of reagents, improvement in productivity, and efficiency of industrial minerals (Nagaraj and Farinato 2016).

Fundamental research relevant to flotation has been wellpresented in the literature and it is crucial for selection of reagents. Recent literature reports on the zeta potential studies of calcite (Dawoud et al. 2017), evolution of calcite flotation chemistry and chemicals (review, Nagaraj and Farinato 2016) have been summarized and discussed in this paper. Additionally, there are several review articles on the reagent adsorption on surface flotation behaviour of salt type minerals and their interaction with reagents, specifically their separation among calcium-containing minerals (Somasundaran 1969; Pradip and Fuerstenau 1985; Rao et al. 1991a, b; Quast 2016; Dawoud et al. 2017). However, until now, no comprehensive study has been presented on the purification of calcite ores from silicates and sulphides by flotation. Thus, this paper summarizes the understanding of the surface properties of minerals and their interaction with reagents which is currently to be found in the literature. The aim of this paper is therefore to discuss the parameters of calcite ore that affect the beneficiation process which are presented as follows: (1) introduction: structure and properties of calcite; (2) reagent systems used for calcite ore flotation: (a) anionic, (b) cationic, (c) non-ionic, and (d) mixed reagent systems; (3) collation and review of the calcite-reagent interaction which includes zeta potential, adsorption, and FTIR studies; (4) flotation studies on different kinds of calcite ores; and (5) patents filed on calcite beneficiation.

\section{Collectors in Calcite Flotation}

There are various kinds of calcite ores in nature and based on the quality of calcite in the ore, they can be regarded as highgrade and low-grade calcite ores. When calcite is present in a very high quantity with a minor amount of associated impurities, it is economically feasible to float the impurities and this process is known as reverse flotation. In some cases, calcite is present in low quantities within significant deposit masses that may be utilized for industrial purposes, in which case they are floated by direct flotation. In most such cases, calcite is accompanied with other Ca-bearing minerals and the beneficiation process is difficult. In the following section, various reagent systems that have been used are presented.

\section{Cationic Collectors}

Cationic reagents are generally used for flotation of silicate impurities from calcite ore. However, there are few Nordic high-grade calcite ore deposits with sulphides and graphite as impurities. Generally, different kinds of amines were used as cationic reagents to float the undesirable impurity minerals from this calcite ore.

From the literature, it can be deduced that amines have already been employed industrially for sulphide flotation from calcite ore. Amines are classified into primary, secondary, tertiary, and quaternary amines on the basis of a number of organic substituents for hydrogen atoms on the nitrogen atom. In the case of quaternary ammonium surfactants, a 4 alkyl or aryl group is attached with one nitrogen at the centre, $\mathrm{NR}_{4}{ }^{+}$ (usually called quats) which binds to an anion, chiefly a chloride. Thus, it explains that although the quats are permanently charged, this charge is independent of $\mathrm{pH}$ in solution (Bulatovic 2007). Recently, Bunkholt and Kleiv (2015) have presented results showing that the pure iron sulphide minerals were optimally floated in the presence of a quaternary amine. There are few studies on sulphide flotation by primary diamines in literature; Kydros et al. (1993) showed that pyrite can be floated with cetyltrimethylammonium bromide (CTMAB) resulting in maximum recoveries at $\mathrm{pH} 3-4$ and decreasing recoveries with increasing $\mathrm{pH}$ although floating at pH 12. Sirkeci (2000) observed a different trend, where HTA (hexyl thioethylamine hydrochloride, a derivative of primary amine) was employed as a collector. Pyrite was not floating until $\mathrm{pH}$ 9.3, and flotation recovery was at a maximum between $\mathrm{pH} 10.5$ and 11.5. Few studies have been performed on the comparison of amines and xanthates. Nanthakumar and Kelebek (2007) conducted flotation 
experiments using EDTA (ethylenediaminetetraacetic acid) and TETA (triethylenetetraamine) and compared it with potassium amylxanthate (KAX) and found that EDTA produced best results at alkaline pH. Similarly, Kongolo et al. (2004) compared Armac C (cocoalkyl amine thioacetate) and KAX to float pyrites and found the recovery was higher with Armac C at $\mathrm{pH} 11$.

The species distribution diagram of diamine collector as a function of $\mathrm{pH}$ at total initial concentrations of $1 \times 10^{-5} \mathrm{M}$ employed in flotation studies is redrawn from Scott and Smith (1991) and presented in Fig. 2. The average alkyl chain of the diamine part of the collector molecule used in this case is about $\mathrm{C}_{16}$. However, the $\mathrm{pKa}_{1}$ and $\mathrm{pKa}_{2}$ values of 6.8 and 9.3 , respectively, for $\mathrm{C}_{12}$ diaminopropane were used since the $\mathrm{pKa}$ values change marginally with chain length. The distribution diagram shows that the amine dissociates mainly into either singly or doubly charged species at and below $\mathrm{pH} 8$ and forms precipitate in the alkaline $\mathrm{pH}$ region above $\mathrm{pH} 8.5$.

In some ores, calcite is present in moderate quantities along with silicates. In such cases, silicates or sulphides associated with calcite are floated using amine surfactants (Hanna 1975). All these experiments were performed at alkaline $\mathrm{pH}$; if silicates or sulphides were present in the ores, these were floated before the separation of scheelite and calcite was performed.

Overall, the flotation of sulphides and silicates with amines from calcite ore showed that at alkaline and neutral $\mathrm{pH}$ region, there is a possibility to float sulphides using amines. The interaction mechanism of these reagents is explained in a later section ("Flotation Studies").

\section{Anionic Collectors}

Generally, calcium-containing minerals are best floated with fatty acids. Sodium oleate was studied broadly to specifically

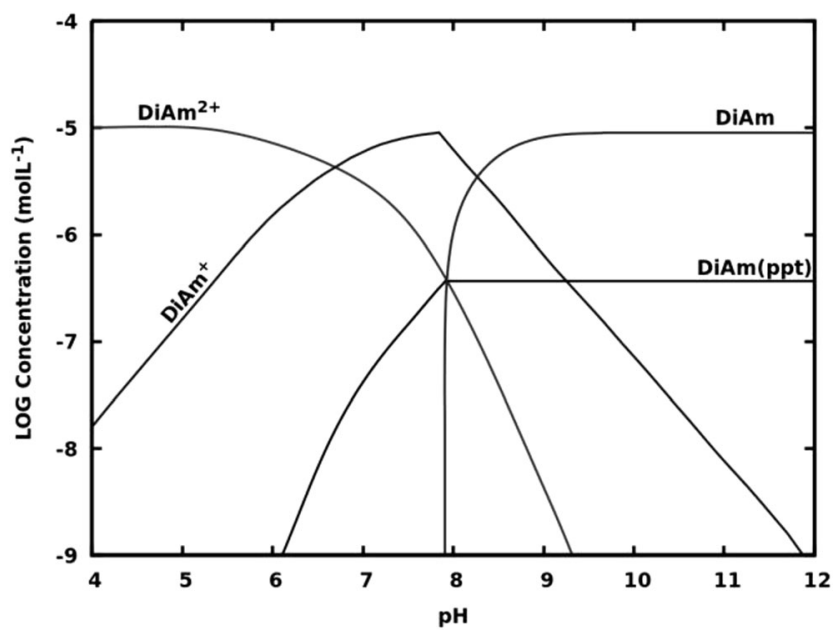

Fig. 2 Species distribution diagram of amine at collector concentration $1 \times 10^{-5} \mathrm{M}$ (redrawn from Scott and Smith 1991) float calcite in several cases. The species distribution diagrams of oleate collector as a function of $\mathrm{pH}$ at total initial concentrations of $5 \times 10^{-4} \mathrm{M}$ employed in flotation studies are redrawn from Han et al. (2017) and presented in Fig. 3. The distribution diagram shows that oleate is in neutral acidic form or colloidal precipitate in the acidic $\mathrm{pH}$ region below $\mathrm{pH} 8.5$. The $\mathrm{pH}$ at which calcite was floated was around 9-11, and in this region, both anionic oleate monomer and dimer species exist. The other flotation conditions depend on the mineral composition in the ore. The various depressants used for calcite depression are presented in a later section ("Flotation Studies").

\section{Mixed Collectors}

Studies on the synergistic effects of collectors were chiefly performed using anionic collectors in combination with nonionic reagents in the past. The presence of nonyl phenol (nonionic surfactant) shows a synergistic effect with oleate reagent by increasing the hydrophobicity at relatively low concentrations of both the reagents (Giesekke and Harris 1994; Sis and Chander 2003; Filippova et al. 2014).

\section{Calcite-Reagent Interactions}

Fundamental studies in the field of flotation have proved to be crucial in the selection of flotation reagents and flotation conditions. The surface chemistry of reagent interaction with minerals is usually comprised of zeta potential experiments, adsorption studies, and flotation tests. In this section, we will summarize the zeta potential and adsorption studies of calcite/impurity minerals with collectors.

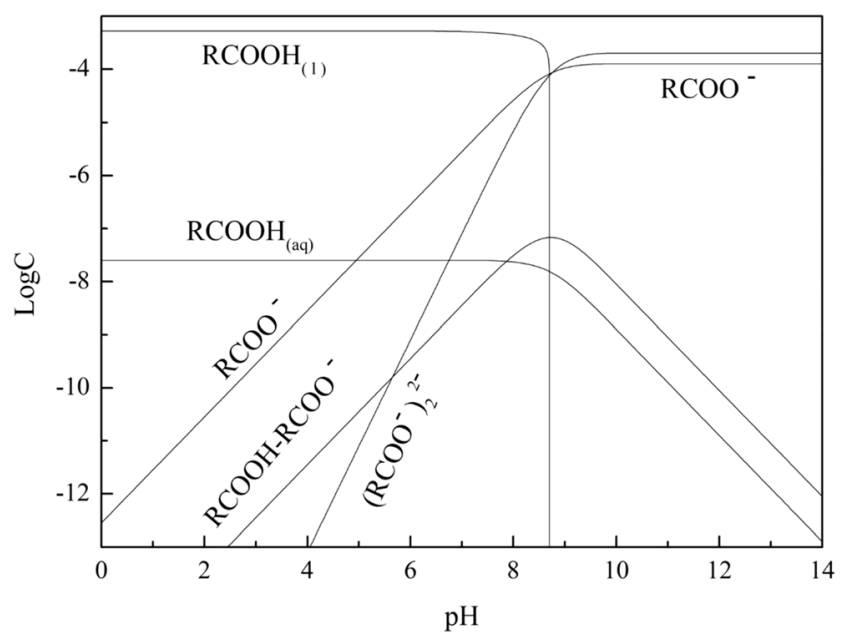

Fig. 3 Species distribution diagram of sodium oleate $\left(5 \times 10^{-4} \mathrm{~mol} \mathrm{~L}^{-1}\right)$ (redrawn from Han et al. 2017) 


\section{Zeta Potential Studies}

\section{Calcite-Oleate Interactions}

The zeta potential of calcite in the aqueous system and in the presence of oleate has already been thoroughly studied by several researchers (Quast 2016; Andersen et al. 1991; Moulin and Roques 2003). Generally, the isoelectric point (IEP) of calcite was approximately $\mathrm{pH} 7-8.5$. The most important factor controlling the surface potential of calcite is the dissolution equilibrium of $\mathrm{Ca}^{2+}$ versus $\mathrm{CO}_{3}{ }^{2-}$ species from the calcite surface. Continuous dissolution and re-precipitation of ions are taking place, and protons and hydroxide ions play a dual role in the determination of the surface potential of calcite. One of the major breakthrough studies in the zeta potential values of calcite was performed by Somasundaran et al. (1996) which was that the isoelectric point of calcite deviated towards a higher value after mixing for 2 weeks with the water from an equilibrated apatite solution. This showed that the isoelectric point of calcite is influenced by the presence of other salt-type minerals (apatite specifically) in the ore. Surface conversions due to reactions of the dissolved species with the mineral surface were studied in parallel using thermodynamic stability diagrams for heterogeneous mineral systems. Both the zeta potential and theoretical calculation results corroborated with each other. Addition of oleate has a major influence on the surface properties of calcite. A brief description of zeta potential results after calcite-oleate interaction is presented below.

Sodium oleate is primarily used as a collector for calciteapatite or calcite-scheelite separation. Calcite, scheelite, and apatite are sparingly soluble minerals and due to its solubility, it is difficult to measure the zeta potential below $\mathrm{pH}$ 7. Almost all the researchers indicated that after increasing sodium oleate concentration, there is an increase in negative values of zeta potential for calcite (Somasundaran 1969; Mishra 1979; Somasundaran et al. 1985; Amankonah and Somasundaran 1985; Rao et al. 1989; Zimmels and Lin 1974; Smith and Shonnard 1986); a few peculiarities are explained below.

In 1996, Somasundaran et al. found that at $\mathrm{pH} 8.2$ and in the presence of $10^{-6} \mathrm{M}$ oleate concentration, the calcite zeta potential was zero (Fig. 4). Below this $\mathrm{pH}$, the values of zeta potential significantly increased with respect to collector concentration, which was attributed to the electrostatic attraction between the negatively charged oleate ions and positive surface sites of calcite. Above $\mathrm{pH}$ 8.6, there were continuous changes in the zeta potential values which indicate specific adsorption of oleate.

In 1974 and 1975, Zimmels et al. presented two articles about the effect on adding sodium oleate on the zeta potential of synthetic calcite; the results are shown in Fig. 5. The figure represents variations in the zeta potential of calcite with oleate as a function of initial and equilibrium concentrations. Below

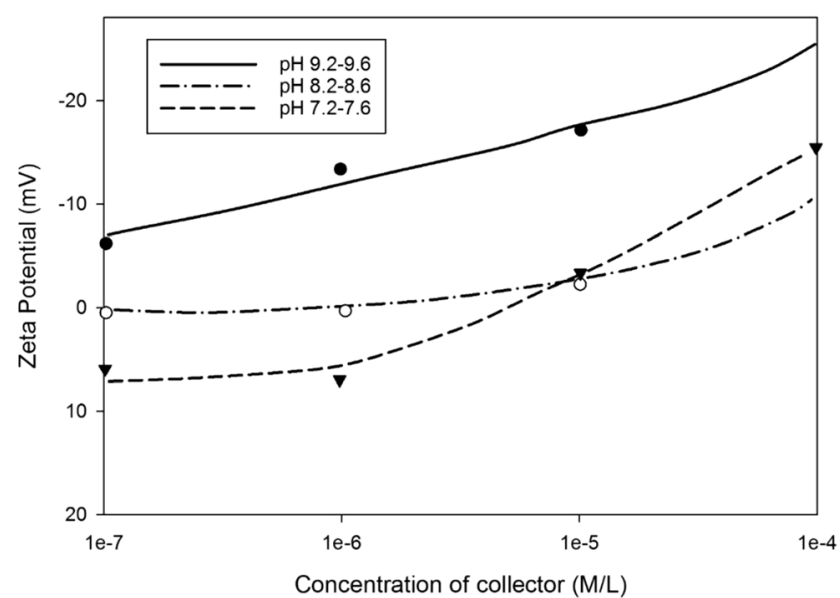

Fig. 4 Zeta potential of calcite as a function of collector concentration (redrawn from Somasundaran 1996)

$2 \times 10^{-4} \mathrm{M}$, initial concentration, there was little increase in the negative value of the zeta potential, which was similar to the results of Somasundaran (1969). In the second region between $2 \times 10^{-4}$ and $8 \times 10^{-4} \mathrm{M}$, the zeta potential gradually changed to a steep increase. In the third region $\left(8 \times 10^{-4}-1 \times\right.$ $10^{-3} \mathrm{M}$ ), the potential was constant at $-50 \mathrm{mV}$ and above at which concentration it gradually decreases. The constant zeta potential at $-50 \mathrm{mV}$ refers to the precipitation of Ca-oleate, which was later substantiated by several researchers (Bulaovic 2007).

Figure 6 shows the various results produced by several researchers on zeta potential values of calcite as a function of initial concentration. This figure was presented by Rao (1992), where the trend is similar for all the studies. At low concentrations, there is a decrease in the zeta potential values referring to chemisorption, but between oleate concentration $1 \times 10^{-5}$ and $1 \times 10^{-4} \mathrm{M}$, the potential remains constant. As the concentration increased, the negative value of zeta

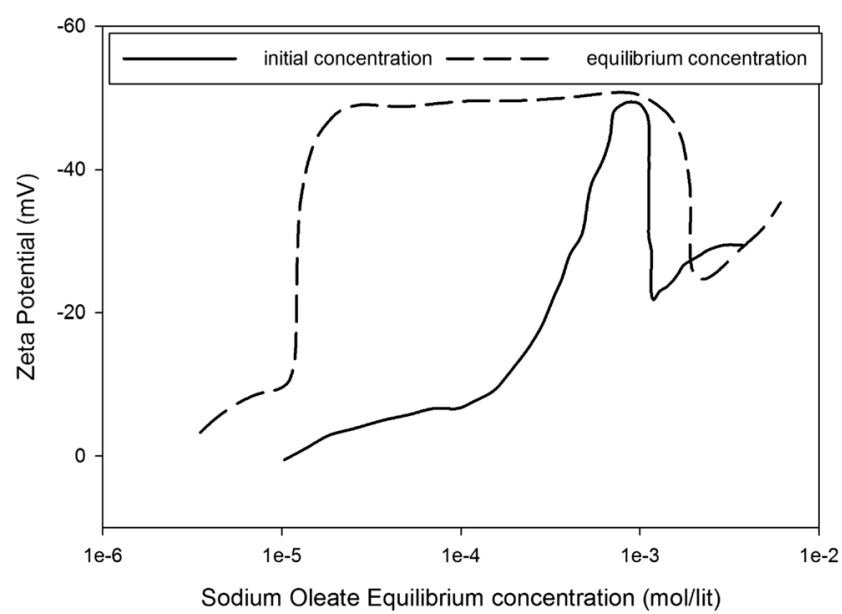

Fig. 5 Variation of zeta potential of calcite with sodium oleate. a Initial concentration. b Equilibrium concentration (redrawn: Zimmels and Lin 1974) 


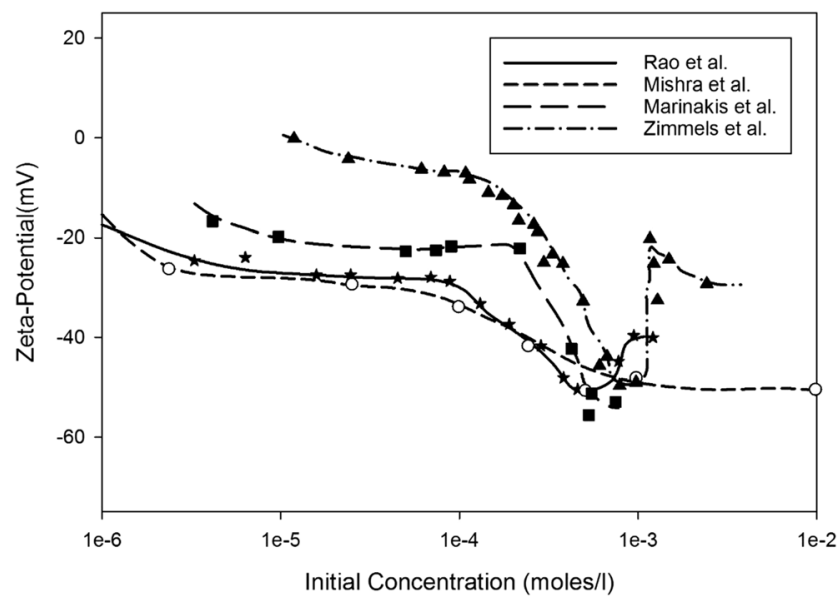

Fig. 6 Comparison of zeta potential of calcite as a function of oleate concentration at $\mathrm{pH} 10$ (redrawn from Rao 1992)

potential dramatically increased and reached a minimum potential of $-50 \mathrm{mV}$, which was attributed to Ca-oleate precipitate.

Sayan (2005) measured the effect of oleate on calcite in alkaline $\mathrm{pH}$ range and reported that the potential was negative and became more negative with increasing sodium oleate addition. The authors explained that this is due to the increasing concentration of negative oleate ions around the calcite particles and this caused an exchange between the oleate ions and carbonate ions on the surface of calcite. Interaction of anionic oleate on the negative calcite surface was due to chemisorption of oleate on surface calcium sites. This interaction led to a more negative surface charge, and therefore, the zeta potential remained negative at all the $\mathrm{pH}$ ranges.

\section{Sulphide-Amine Interactions}

Little literature is available about the interaction of sulphides and calcite with amine collectors. Kydros et al. (1993) studied pyrite interaction with amines and found that the zeta potential was zero for pure pyrite mineral at $\mathrm{pH} 2.5$ which was similar to the previous results of Leja (1982). However, after the addition of amine collector, the IEP shifts to around $\mathrm{pH}$ 6-7, showing electrostatic adsorption of positive amine on negative sulphide minerals. Sirkeci (2000) indicated that the IEP of pure pyrite was around 6.3 which was shifted to $\mathrm{pH} 6.9$ on the addition of amines. These results were very different from those of Kydros et al. (1993); however, they also observed that the zeta potential values were highly negative at $\mathrm{pH} 11$.

Bunkholt and Kleiv (2014) reported that the zeta potential of pyrrhotite in quaternary amine solution remained positive throughout, although there is a steep increase at $\mathrm{pH} 11$ due to adsorption of amine precipitate species. In this study, the IEP of pyrrhotite was extrapolated and found to be at less than $\mathrm{pH}$ 7. Similarly, for pyrite, the zeta potential in aqueous solution was reported to be negative before $\mathrm{pH} 10.5$ which had a steep rise after the IEP ( $\mathrm{pH}$ 10.5). Pyrite, when conditioned with amines, was negative throughout the range $7-11$, but became positive just after that, becoming completely positive at $\mathrm{pH} 11$. Thus, this result shows that amine precipitate species adsorb on the pyrite particles. This was different from the results of Sirkeci (2000) who observed negative zeta potential values at $\mathrm{pH} 11$. Overall, it is well-understood from the above studies that sulphides are positive in the alkaline range from 7 to 11 , whereas calcite is negative in the same $\mathrm{pH}$ range which clarifies that it is possible to float sulphides using amines in the alkaline $\mathrm{pH}$ range. However, as amine protonated to positively charged ions, it will preferably attach to the negatively charged sulphides in the alkaline $\mathrm{pH}$ range.

\section{Adsorption Studies}

The anionic oleate and cationic amine collector adsorption theories proposed by various researchers are briefly summarized in this section. The adsorption mechanism of these surfactants on calcite surfaces differed and was explained as columbic, chemical, and surface precipitation reactions. Several theories were proposed to explain the nature of adsorption of the long-chain surfactants on mineral surfaces.

Gaudin and Fuerstenau (1955) suggested that the longchain surfactants are adsorbed as individual counter-ions at low concentrations and hemimicelle structures due to chainchain bonds that are formed between the adsorbed long-chain molecule in the stern layer which takes place above a critical equilibrium concentration, termed as the critical hemimicelle concentration. Later, Cases (1979) and Cases et al. (1986) introduced a stepwise adsorption model based on thermodynamic considerations such as potential energy and entropy of the adsorbed layer as well as the heterogeneity of adsorbent surfaces. Due to the surface heterogeneities, the twodimensional condensation takes place because of lateral hydrophobic chain-chain bonds on the most energetic homogeneous domains initially at lower concentrations. Successive two-dimensional condensation of surfactant occurs on the following lesser energetic domains of the surface with increasing concentration. Thus, within the monolayer, the isotherm shows a stepwise increase in adsorption, i.e. a series of small vertical steps, or a smooth curve depending on the distribution of surface energetic domains (Fig. 7). The second layer is always characterized by a vertical step since the surface is rendered homogeneous due to the formation of a first layer. Harwell et al. (1985) proposed an admicelle hypothesis, which states that the surfactant aggregation producing the admicelle structures forms locally on the surface due to heterogeneity in the same manner as micelle formation. These admicelles form on a given patch of the heterogeneous surface at a critical solution concentration, and for concentrations, less than this value, aggregates do not exist on that patch. However, Cases (1989) later explained that this admicelle hypothesis is just an 


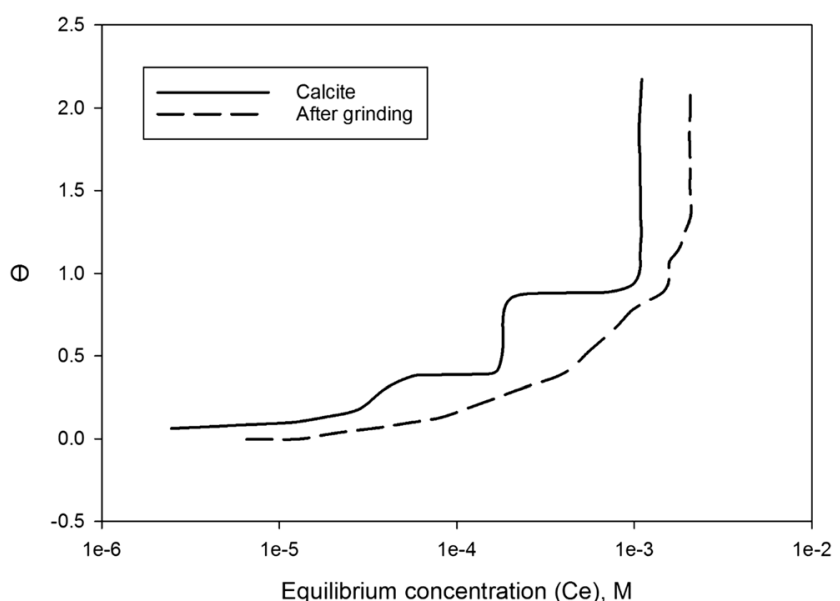

Fig. 7 Adsorption isotherms at $25{ }^{\circ} \mathrm{C}$ and $\mathrm{pH} 8.3$ of alkyldodecylammonium chloride on synthetic calcite, before (curve I) and after fine-grinding (curve II) isotherms of adsorption at $25^{\circ} \mathrm{C}$. and $\mathrm{pH} 8.3$ of alkyldodecylamine chloride on a synthetic calcite (Cases et al. 1986; Goujon and Mutaftschie 1976)

extension to their two-dimensional condensation model. Later, Somasundaran et al. (1985) stated that the adsorption of oleate on semi-soluble minerals is in fact a surface precipitation which they have substantiated by calculating the concentration of the counter-ions at the surface region whereby the solubility product for precipitation reached at the surface region first before in the bulk solution.

For studying the adsorption model of oleate on calcite, concentration-pH factors were chosen and tested by various researchers. Jung (1976) and Jung et al. (1988) stated that when the solution conditions devoid of liquid oleic acid and $\mathrm{NaH}(\mathrm{OL})_{2}$ prevailed, calcium oleate is the adsorbed species. Oleate ions are the predominant species at basic $\mathrm{pH}$ values, and therefore, it is not worth experimenting at lower $\mathrm{pH}$ values where undissociated oleic acid exists in the form of colloidal precipitate. The concentration range of oleate studied in most cases exceeds the solubility limit of calcium oleate considering the dissolved calcium ions from the minerals; the solubility product of calcium oleate is reported to fall in the $\mathrm{pK}$ range of 12.4-15.74. However, Cases et al. (1986) showed that there will be no confusion between the adsorption and precipitation since the isotherms indicate an infinite vertical step following precipitation under conditions of excess ions in solution.

As presented in the above section, the deviations in zeta potential and ambiguities with the shape of adsorption isotherms have attracted many researchers to investigate the calcite-oleate system. Somasundaran (1969) proposed hemimicelle formation at $\mathrm{pH} 9.6$ (oleate concentration around 2 to $3 \times 10^{-6} \mathrm{M}$ ). He observed a sharp increase in the slope of the adsorption isotherm above $3 \times 10^{-5} \mathrm{M}$, and this increase was attributed to the precipitation of calcium oleate. The concentration of calcium at the interfacial region was calculated using the Boltzmann equation and the pKa value of calcium oleate for precipitation satisfaction from the beginning of low oleate concentrations, thereby showing that the abstraction of oleate by calcite is not adsorption but surface precipitation.

Iskra et al. (1973) observed the adsorption of oleate remains constant in the $\mathrm{pH}$ range 8.6-12.0. On the other hand, Gutierrez (1979) claimed that adsorption was pH-dependent and at maximum between $\mathrm{pH} 10.2$ and 11.5. The author also reported a steep increase in the slope of isotherm above $4 \times$ $10^{-5} \mathrm{M}$ equilibrium oleate concentration, which was similar to that reported by Somasundaran (1969). The reason stated was also the same, i.e. precipitation of calcium oleate.

Other works presented by Zimmels and Lin (1974) and Zimmels et al. (1975) describing a three-stage adsorption model of oleate on calcite consist of direct monomer, hemimicelle, and micelle adsorption based on their affinities for adsorption at different oleate concentrations (Fig. 8). Physical adsorption and chemisorption were considered for the adsorption of either monomer or aggregate of oleate species. This model of physical and chemisorption of oleate on calcite was similar to the results of Szezypa et al. (1979) and Fuerstenau et al. (1968) for sodium laurate.

Another important conclusion drawn by Marinakis and Shergold (1985) was the abstraction of oleate by calcite with the precipitation of calcium oleate for the range of oleate concentration studied. The results are shown in Fig. 9. The experimental and theoretical oleate concentrations for calcium oleate precipitation match in the entire concentration range studied, and thereby, the authors claim that the adsorption is only due to calcium oleate precipitation. However, Rao et al. (1989, 1991a, b, c) showed such a correlation between the experimental and theoretical concentration happens only after $5 \mu \mathrm{mol} \mathrm{m}{ }^{-2}$ corresponding to a monolayer coverage in a liquid crystal state.

Kulkarni (1975) explained the governing role of the oleic acid-oleate complex (later termed as iono-molecular complex/ acid-soap complex, Somasundaran 1975) in determining the $\mathrm{pH}$ dependence of oxide flotation using oleate. The $\mathrm{pH}$ of the

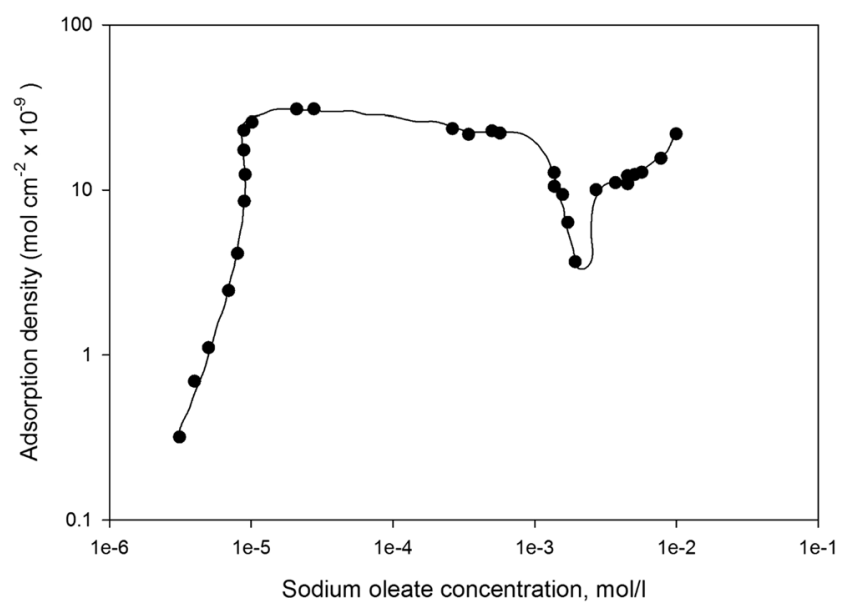

Fig. 8 Adsorption isotherm of sodium oleate on calcite (Zimmels and Lin 1974) 


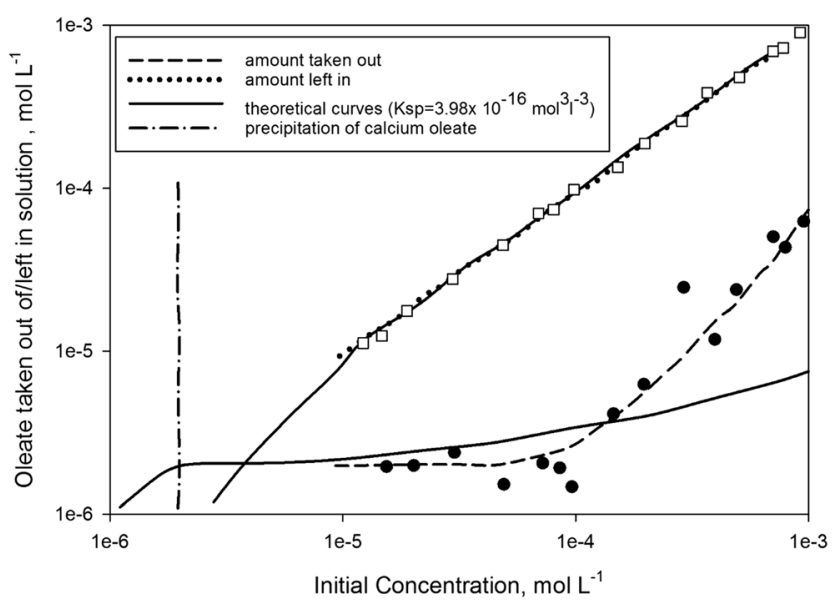

Fig. 9 Amount of oleate abstracted from solution in equilibrium with $0.1 \mathrm{~g}$ calcite at $\mathrm{pH}$ 10. (redrawn from Marinakis and Shergold 1985)

maximum flotation response was found to be identical to the $\mathrm{pH}$ of the maximum concentration of the acid-soap complex. It was also shown that the maximum in both surface tension decay rate, as well as surface tension lowering, was obtained for oleate solutions at the same $\mathrm{pH}$ which suggested that the higher surface activity of the acid-soap complex compared with that of the acid or the soap to be one major reason for the observed $\mathrm{pH}$ effect on flotation response. Later, many researchers also reported the influence of acid-soap complex species on various minerals, including carbonates (Young and Miller 2007). However, Chernyshova et al. (2011) performed spectral investigations and showed that acid-soap dimers in the bulk solution did not directly associate with mineral hydrophobicity.

Later in 1989(b), Antti and Forssberg reported the formation of a new species $\mathrm{CaOHOl}$ at $\mathrm{pH}$ greater than 10.35 , for the reduction in calcite recovery at $\mathrm{pH} 10$ and 11 . Additionally, the mineral surface became less hydrophobic only if it was covered with a layer of $\mathrm{CaOHOl}$ instead of $\mathrm{Ca}(\mathrm{Ol})_{2}$ which was obtained slightly at lower $\mathrm{pH}$. They also stated that even at lower $\mathrm{pH}$ value, $\mathrm{CaOHOl}$ is formed first and deposited in a monolayer on the mineral surface. Precipitated $\mathrm{Ca}(\mathrm{Ol})_{2}$ can then be adsorbed to the mineral surface by physisorption, making the surface more hydrophobic.

According to the series of papers published by Rao et al. (1989, 1991a), the interaction of oleate on calcite corresponded to the adsorption of oleate until monolayer coverage and physical adsorption of precipitated calcium oleate at a higher concentration similar to previous studies. Young and Miller (2007) studied the adsorption of oleate on calcite at $\mathrm{pH}$ 9.2. The incomplete monolayer was observed at equilibrium oleate concentrations below $1 \times 10^{-5} \mathrm{M}$, and multilayer coverage was observed at higher concentrations (> $\left.10^{-4} \mathrm{M}\right)$. According to these authors, chemisorption at low oleate concentrations and surface precipitation of calcium oleate at higher concentrations occurred.
Recently, Sayan (2005) performed adsorption studies and concluded that oleate adsorption increased with increasing addition up to critical micelle concentration, after which increasing oleate addition caused lower adsorption due to the formation of oleate micelles in the solution rather than surface oleate compounds.

\section{FTIR Studies}

The qualitative adsorption of oleate on calcite was assessed by several FTIR investigations. Generally, oleate adsorbs chemically on calcite by the carbonyl adsorption band; however, the exact position of the band was stated to be uncertain owing to the highly interfering carbonate absorptions. Peck (1963) and Peck and Wadsworth (1964) indicated a shift in the peak from 1562 to $1555 \mathrm{~cm}^{-1}$ after washing and assigning the peak at $1555 \mathrm{~cm}^{-1}$ to surface calcium oleate which is thought to be obscured by the peak at $1562 \mathrm{~cm}^{-1}$ for sodium oleate after adsorption. The bands at 1562 and $1555 \mathrm{~cm}^{-1}$ were assigned to physically adsorbed sodium oleate and surface calcium oleate, respectively. However, the same authors in a subsequent investigation considered the peak at $1562 \mathrm{~cm}^{-1}$ for the surface calcium oleate and the physically adsorbed sodium oleate and suggested that it is not possible to distinguish between them. Kellar et al. (1990) characterized the mono-coordinated calcium oleate (chemisorbed) by an absorption band at $1549 \mathrm{~cm}^{-1}$ by using in situ internal reflection FTIR spectroscopy. Double peaks corresponding to calcium oleate were observed in other studies.

Antti and Forssberg (1989) studied the calcite-oleate system by FTIR studies and found that the composition and surface structure of the mineral influence the adsorption process. They also concluded that the adsorption density was higher at pH 9 and 10 than at $\mathrm{pH} \mathrm{11;} \mathrm{however,} \mathrm{precipitation} \mathrm{of} \mathrm{calcium}$ oleate after the monolayer was attributed at all the $\mathrm{pH}$ values 9,10 , and 11 . The monolayer was formed with 1:1 coordination of oleate with calcium. Thus, the result agreed with the previous adsorption studies.

Young and Miller (2007) recorded the in situ and ex situ FT-NIR/IRS spectra of oleate adsorption on the calcite surface. The spectral quantitative absorption data was presented as the adsorption isotherms (Fig. 10) and its dependence on temperature and $\mathrm{pH}$. The isotherm is basically divided into two regions. Region 1 is below $1 \times 10^{-5} \mathrm{M}$ oleate concentration at sub-monolayer, and region 2 corresponds to a multilayer coverage at higher oleate concentrations. The concentration of oleate below $1 \times 10^{-4} \mathrm{M}$ dimers in solution is formed which slowed down the reaction kinetics. At a concentration of around $1 \times 10^{-3} \mathrm{M}$, the adsorption density decreases due to micelle formation and below $2 \times 10^{-3} \mathrm{M}$ was attributed as $\mathrm{CMC}$ and many dimers were formed between $1 \times 10^{-4}$ and $2 \times 10^{-3} \mathrm{M}$. Region 1 represented oleate chemisorption and 2 calcium oleate precipitation. The precipitation reaction is as 


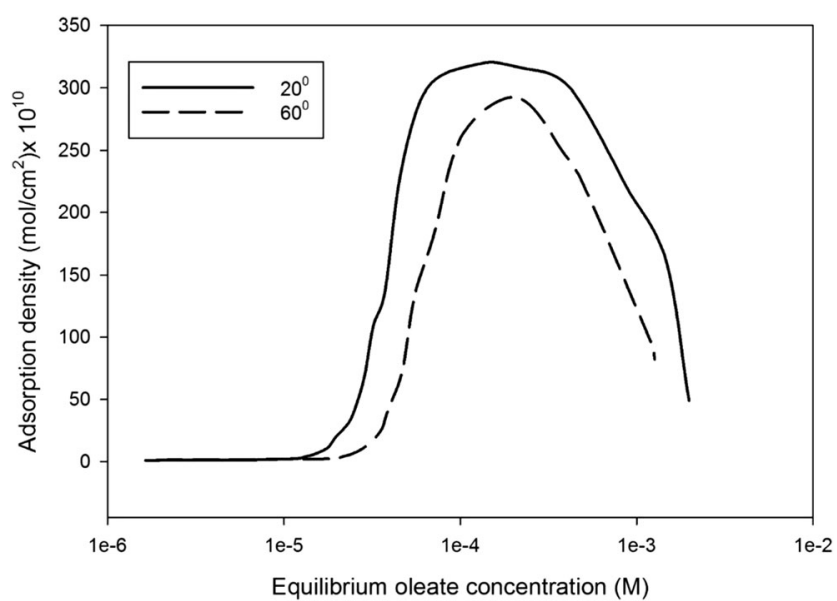

Fig. 10 Oleate adsorption isotherms determined for calcite at $20{ }^{\circ} \mathrm{C}$ and $60{ }^{\circ} \mathrm{C}$ and at $\mathrm{pH} 9.2$ by in situ FT-NIR/IRS with overtone and combination bands of the aliphatic stretch from Young and Miller (2007) (calcite at pH 9.2)

follows:

$\mathrm{Ca}^{2+}+2 \mathrm{Ol}^{-}=\mathrm{Ca}(\mathrm{Ol})_{2}(\mathrm{ppt})$

Oleate chemisorption has given an equation which was later used by Young and Miller (2007):

$$
\mathrm{Ca}\left[\mathrm{X}\left(\mathrm{H}_{2} \mathrm{O}\right)_{\mathrm{n}}+\mathrm{NaO}\right]=\mathrm{CaOl}\left(\mathrm{H}_{2} \mathrm{O}\right)_{\mathrm{n}-\mathrm{m}}+\mathrm{m} \mathrm{H}_{2} \mathrm{O}+\mathrm{NaX}
$$

They concluded that in situ FT-NIR/IRS spectra have shown that $\mathrm{D}_{2} \mathrm{O}$ restructures at the calcite surface upon wetting and upon addition of oleate. The isotherm is presented below.

Sayan (2005) suggested that Na-oleate chemically adsorbs on the calcite surface, which interacts with oleate ions, giving the surface calcium oleate product. Ca-oleate is waterinsoluble and remains on the calcite surface as 1:1 coordination species.

Sirkeci (2000) studied the amine-sulphide adsorption system and reported that a weak peak was observed for pyrite that interacted with HTA at $\mathrm{pH}$ 5, which means HTA adsorbs on to the surface of pyrite to a much lesser degree at acidic $\mathrm{pH}$ values compared with an alkaline range. There is a need to perform a detailed study in order to develop a better understanding of the calcite- amine system.

\section{High-Grade Calcite Ore Deposits}

Our study is primarily focussed on the high purity calcium carbonate deposits in the world, comprising a high-quality raw material for GCC production. Many such deposits are located in the Nordic region of Europe, which are listed below.
Akselberg Calcite Deposit The Northern-Norway marble deposit is one of the major high purity calcium carbonate deposits with minor inclusions of graphite and sulphides in the world, comprising a high-quality raw material for GCC production (Watne 2001). It was later demonstrated by Bunkholt and Kleiv $(2014,2015)$ that the deposit contains a substantial volume of sulphide-bearing marble, where the main contaminant phases are pyrite and pyrrhotite, the latter being the most abundant contaminant. The presence of sulphides was responsible for the colouring effect, which reduces the brightness of marble.

Kurikka Calcite Marble Deposit A high-grade calcite deposit, which was mainly composed of calcite, silicates (quartz, tremolite, feldspars, diopside, mica, and serpentine), and graphite from sub-microscopic size to about $0.2-1.5 \mathrm{~mm}$, and rarely, hydrated iron oxide and sulphides (Chernet et al. 2006). The authors mentioned that the presence of fine-grained graphite in the deposit was responsible for the uneven grey colour of the calcite marble and it also lowers the deposits' grade as a source for GCC (Pekkala 1985).

Gåsgruvan Deposit Sweden has a high-grade calcite deposit with minor impurities of silicates (quartz), which reduces its industrial applications. It was studied by Rao and Forssberg (1991) and Rao and Forssberg (1993).

A low-grade calcite deposit located in Tamil Nadu, India, was studied by Srinivas et al. (2011). The feed material analysis showed that the average particle size was $37 \mu \mathrm{m}$ and that $\mathrm{d}_{80}$ was $63 \mu \mathrm{m}$. Petrological studies indicated the presence of quartz, feldspar, pyroxene, and mica as the major silicate gangue minerals. Liberation studies were performed and found that the majority of these silicates are liberated from the selected feed size material $(-63 \mu \mathrm{m})$. A few silicate grains, in the size range from 5 to $15 \mu \mathrm{m}$, remained locked within the calcite grains as inclusions and appeared in the concentrate. Another important calcite deposit (Nigde region in Turkey), with scheelite and quartz as impurities, was also studied by Ozcan et al. (1994).

\section{Flotation Studies}

\section{Pure Mineral Flotation}

\section{Cationic Reagents}

Table 1 presents and discusses research studies on the flotation of various calcium-bearing pure minerals, silicates, sulphides, and mixed sulphide-silicate minerals.

The flotation of sulphides and quartz from calcite is possible while using an amine collector at neutral or mildly alkaline $\mathrm{pH}$ values where the amines are present in mono and doubly 
Table 1 Pure mineral flotation overview in the presence of cationic reagents

\begin{tabular}{|c|c|c|}
\hline Author & Reagents used in the study & Minerals in the study \\
\hline Atademir et al. (1981) & $\begin{array}{l}\text { Dodecylamine hydrochloride (DAC) and octadecyl } \\
\text { pyridinium bromide (ODPB), 4-tertiary butyl } \\
\text { catechol (TBC)-chelating collectors }\end{array}$ & Calcite, scheelite, fluorite, and barite \\
\hline
\end{tabular}
calcite more effectively than any other mineral, giving high recovery from $10^{-3}$ to $10^{-2} \mathrm{M}$ solutions at $\mathrm{pH} 9.5$.

Arnold et al. (1978) Dodecylammonium chloride (collector), calcium chloride Scheelite and calcite

Results: In the case of calcite flotation, calcium chloride ( $\mathrm{or}_{\mathrm{Ca}}{ }^{2+}$ ions) had no immediate effect on flotation recovery. At low collector concentrations, significant depression of calcite occurred after several hours standing in the presence of calcium ions.

Irannajad et al. (2009)

Primary amine collectors (cationic) (Armac C, Armac T, Flotigam SA, Flotigam TA and Armeen TD), anionic collector (oleate); depressants: sodium hexa-metaphosphate, sodium silicate, starch

Results: At pH 11 and 400 g/tonne of Armac C, the recovery of calcite was 89\%. Various depressants were tested; sodium silicate and starch could not depress the calcite in both cationic and anionic flotation conditions. Sodium hexa-metaphosphate acted as a calcite depressant for cationic flotation.

Gang et al. (2009)

$N$-Dodecylethylenediamine (ND) and dodecylamine

Quartz, calamine, iron oxide minerals and calcite

Results: ND reagent has a strong propensity towards quartz and calcite (max-95.99\% recovery) above $\mathrm{pH} 7$. However, dodecylamine was a better calcite collector. Amine collectors are usually used as the common oxide minerals collectors, and the bonded atom in them is nitrogen. When the hydrogen is replaced by different radicals, the electron cloud density of nitrogen is changed. So, the collecting capabilities of amines are changed. ND was obtained by replacing the hydrogen of dodecylamine radical $-\mathrm{CH}_{2} \mathrm{CH}_{2} \mathrm{NH}_{2}$. The electronegativity of the ND group is 3.9 and dodecyl group is 3.7, which thus has stronger collecting capabilities for oxide minerals.

Hu et al. (2011) Dioctyl dimethyl ammonium bromide (BDDA) Scheelite, calcite

Results: Recovery of calcite is highest around pH 12 (ca 80\%). Calcite becomes soluble below pH 6, and thus, the single-mineral flotation results depicted in this article suggest a preferential flotation separation of calcite from scheelite at a pulp pH between 7 and 9. Although the collector is capable of separating calcium minerals, the adsorption mechanism is different from oleate. Considering the electronic components of nitrogen and the dimensional structure of BDDA, adsorption via a chemical mechanism on the calcium minerals through the nitrogen atom is not preferable. Specifically, one aspect is the surface atoms of the mineral are inaccessible for the nitrogen atom because of the steric effects of its four alkane substituents. Alternatively, the ionic form of nitrogen of BDDA has no lone electron pair to form covalent bonds with metallic atoms. Therefore, BDDA is most likely to physically adsorb on calcium minerals through electrostatic reaction.

Mehdilo and Irannajad (2015) ～～Primary amines (Armac C) Calcite, quartz, smithsonite, zinc oxide

Results: High recoveries of calcite at alkaline $\mathrm{pH}$ values. Armac $\mathrm{C}$ is physiosorbed on the calcite (shown by spectral studies) which is due to the activation of the calcite surface by some anions present in the flotation system.

Bunkholt and Kleiv (2015) $\quad \begin{gathered}\text { Quaternary amine collector (Armofloat } 18 \text { (dicoco } \\ \text { dimethyl ammonium chloride)) }\end{gathered} \quad$ Pyrite, pyrrhotite

Results: Best $\mathrm{pH}$ range for floating sulphides is at $\mathrm{pH} 8-9$, and above this $\mathrm{pH}$, flotation of sulphide decreases which is correlated to the zeta potential studies. Calcite floatability was low at neutral or near-neutral $\mathrm{pH}$ values.
Dhar et al. (2019)
Duomeen $\mathrm{T}$
Pyrite, pyrrhotite

Results: Optimum $\mathrm{pH}$ range for floating sulphides is at $\mathrm{pH}$ 6-9 which is correlated to the zeta potential and FTIR studies. Calcite floatability was low at neutral or near-neutral $\mathrm{pH}$ values. 
charged ions. Optimum results were also observed above $\mathrm{pH} 10$, where the neutral amine molecules are in colloidal precipitate form interacting with the sulphides (explained in the previous section). However, a few studies claimed that amines are capable of floating calcite at and above $\mathrm{pH} 10$. Thus, it can be summarized that $\mathrm{pH} 7-8$ is the most suitable $\mathrm{pH}$ for sulphide/silicate flotation from calcite. Collector concentration, flotation and conditioning times are other parameters, having a higher impact on these flotation results. Considering the above results and the species distribution diagram of amine, it could be stated that below $\mathrm{pH} 8$, sulphideamine interaction is due to electrostatic Coulombic interaction, whereas above $\mathrm{pH} 8$, neutral amine precipitate species physically adsorb on calcite. The pure mineral flotation results correspond well with zeta potential and adsorption studies.

\section{Anionic Reagents}

The floatability of calcite in the presence of anionic collectors is studied in this section. Sodium oleate is generally used as the collector for separation of calcite and other calcium-containing minerals. Hallimond flotation tests and single-mineral flotation tests were performed using pure minerals of calcite, apatite, scheelite, fluorite etc. (Ananthapadmanabhan and Somasundaran 1984; O’Connor et al. 1987; Mishra 1982; Yongxin and Changgen 1983; Atak et al. 1986; Baldauf et al. 1986; Finkelstein 1998; Gallios and Matis 1989; Zhang et al. 1999; Feng et al. 2015; Laskowski et al. 1991; Morozov et al. 1992; Valdivieso et al. 2000; Shi et al. 2012). Usually, a modifier or depressant (sodium metasilicate, Alizarin S, cashew gum, starch, etc.) is used to depress selectively one of the minerals (Fu and Somasundaran 1986; Mishra 1982; O'Connor et al. 1987). Several studies were conducted on the calcite-apatite system and several chemicals were tested as depressants. For example, sodium metasilicate and Acrol LG-21 are calcite depressants (Mishra 1982; O'Connor et al. 1987; Orthgiess and Dobiáš 1994; Sadowski 1990).

Generally, the results showed that in the presence of oleate, effective separation among salt-type minerals is observed in between $\mathrm{pH} 8$ and 10. In most cases, it was noted that there is a steep rise in the recovery of calcite at about $1 \times 10^{-5} \mathrm{M}$ concentration, which is again constant until $1 \times 10^{-4} \mathrm{M}$ (Mishra et al. 1980; Rao et al. 1989). The results are in agreement with zeta potential and adsorption studies.

Recently, a study on tailor-made reagent derivatives with two functional groups that are spaced with increasing distance was performed by Karlkvist et al. (2015) where the carboxylate surfactants, disodium $\mathrm{N}$-dodecanoylaminomalonate (C12MalNa2), disodium N-dodecanoylaspartate (C12AspNa2), and disodium $\mathrm{N}$-dodecanoylglutamate $(\mathrm{C} 12 \mathrm{GluNa} 2)$ having one, two, or three methylene groups between the two anionic groups, respectively, were tested for flotation of pure calcite and apatite. A monocarboxylate surfactant, sodium N- dodecanoylglycine (C12GlyNa) floated calcite with no effect on apatite flotation, whereas with $\mathrm{C} 12 \mathrm{MalNa} 2$, apatite was seen to float well and no effect on calcite flotation. These results illustrate a geometric, electrostatic, and stereochemical compatibility between the mineral surface and anchoring surfactant molecule to achieve selective flotation between two calcium minerals.

Overall, most of the studies reported optimum flotation conditions of calcite recovery above $\mathrm{pH} 8$ with anionic collectors. A few researchers have claimed that calcite flotation is independent of $\mathrm{pH}$ and some other studies showed that the depression of calcite is possible between $\mathrm{pH} 8$ and 10 while separating it from other salt-type minerals. The IEP of calcite was at $\mathrm{pH} 8$ and the microflotation studies corroborate with the zeta potential and adsorption results either with anionic or cationic collector. Generally, sodium silicate or metasilicate was used as a depressant in most of the separations. There were some non-traditional reagents such as hydroxamic acid (Ni and Liu 2013; Yu et al. 2014; Wu and Zhu 2006); amphoteric collectors like alpha-benzol amino benzyl phosphoric acid, BABP (Hu and Xu 2003) and N-hydroxyamino-alkylamide (Deng et al. 2016) used at alkaline $\mathrm{pH}$ to separate from one calcium mineral to the other.

\section{Mixed Reagents}

Mixed reagents were used for flotation of various mineral combinations, and our prime concern is if one among those minerals is calcite. Valdiviezo and Oliveira (1993) performed a few tests with cationic-anionic reagents while most of the other studies were performed on anionic-non-ionic reagent pairs (Giesekke and Harris 1994; Sis and Chander 2003; Filippov et al. 2012; Filippov and Filippova 2006; Filippova et al. 2014). The adsorption mechanism was primarily synergistic; however, a few instances of competitive interaction were also observed. The basis was mainly the interaction of reagent constituents where the polar reagent initially adsorbs on the mineral surface and, subsequently, the non-ionic reagents adsorb via hydrophobic interactions. Overall, it can be stated that by addition of non-ionic surfactants, the concentration of traditional surfactant usage can be controlled as all these studies indicate that total chemical content used in the reagent mixture was lower than that of single reagent systems (Gao et al. 2015).

\section{Bench-Scale Flotation Results}

\section{Cationic Reagent}

After the zeta potential, adsorption, and pure mineral flotation studies, a detailed overview about the flotation of calcite ores is presented below. High-grade calcite ores generally contain silicates or sulphides as impurities and are beneficiated by 
reverse flotation using cationic reagents. Table 3 presents the bench-scale flotation results of calcite ores when cationic reagents were used for floating the impurity minerals.

In general, the bench-scale flotation results are dependent on two major parameters: (1) collector concentration and (2) pH. Srinivas et al. (2011) showed that collector concentration is the most important parameter to control the grade and recovery. Their study concludes that with increasing collector concentration, there is an increase in calcite grade, which is highest at $400 \mathrm{~g} /$ tonne and decreases beyond this dosage. Bunkholt and Kleiv (2015) claimed that there is not any significant increase in the brightness or grade with increasing collector concentration; however, they stated that $\mathrm{pH}$ variation above $\mathrm{pH} 9$ decreases the grade and brightness of the product. They also showed that adding more collector concentration can solve the problem as the decrease in the results was attributed to oxidation of sulphides. Earlier Rao and Forrsberg (1993) suggested that quartz can be floated from calcite efficiently at $\mathrm{pH} 6$ and variation of $\mathrm{pH}$ has a strong influence on the recovery. Thus, it can be concluded that at optimum amine concentration and $\mathrm{pH} 7-8$, it is possible to float sulphides from calcite ore. The results corroborate with the pure mineral studies, as the concentration of positively charged amine ions is greater in the $\mathrm{pH}$ region 6 to 8 or 9. At alkaline $\mathrm{pH}$ region, the amine precipitate could interact with the silicates or sulphide minerals, which are negatively charged.

A detailed overview of cationic reagents is presented in Table 2, which contains information regarding the cationic reagents used in past years for direct flotation of impurity minerals from calcite ores.

\section{Anionic Reagents}

Sodium oleate was generally employed as a reagent for calcite direct flotation from calcite-apatite or calcitescheelite ores (Abouzeid and Elgillani 2009; Elgillani 1978; Prasad et al. 1994; Castro and Calero 1993; Castro et al. 1996; Ribeiro et al. 2003; Abdel-Khalek 2000; Rao et al. 1985; Jena et al. 2013; Santos et al. 2015). Later, due to the complexity of several ores, few modifiers and depressants were employed to facilitate the flotation process. The commonly used modifier was sodium silicate (Prasad et al. 1994; Jena et al. 2013), sodium hexa-metaphosphate (Schubert et al. 1990; Gibson et al. 2015), and hydrated/ acidified sodium silicate (Zhou and Lu 1992; Martinez et al. 2000). A few studies have also reported the unconventional depressants, such as cashew gum (Ribeiro et al. 2003), when it was used as a depressant for calcite, and $70-80 \%$ calcite was recovered as tailings. Similarly, Ozcan et al. (1994) used quebracho as a depressant for separation of scheelite and calcite at $\mathrm{pH} 8-8.5$, which also catalyzed in the presence of the collector oleoyl sarcosine. Although, conventionally, calcite was directly floated using oleate or hydroxamic acid as collector, the process has a significant disadvantage: As mentioned earlier, chemical treatments as collector agents are used to render the surface of the calcite hydrophobic to separate these particles from the impurity minerals. These collector agents are adsorbed on the surface of the calcite and, therefore, modify the properties of the final product (for example GCC feed).

However, these alterations may be undesirable in the following uses of the white pigments in paper, plastics, paint, coatings, concrete, cement, cosmetic, water treatment, food, pharma, ink, and/or agriculture applications. Furthermore, the direct flotation of the desired calcite is also disadvantageous due to quality and economic reasons in these industries. Thus, in the next section, we will focus on the patents filed for highgrade beneficiation of calcite mineral.

\section{Patents in High-Grade Calcite Beneficiation}

The patents published on high-grade calcite beneficiation are either based on the development of the grinding process flowsheet or the reagent scheme used in flotation. This study is based on collector systems; thus, the different reagent schemes patented for calcite ore flotation are discussed below (Table 3). In most of the work presented in the table, the flotation results are assessed by grade/recovery, acid-insoluble tests, and brightness analysis. Table 3 indicates that environmentally friendly reagents such as quaternary amines, ester quats, and microbialbased collectors have been used as the surfactants in the past decade. However, limited studies related to the interaction mechanism of such collectors with metal sulphides have been performed. Such studies could lead to better development of non-toxic collectors for impurity mineral flotation from calcite ores.

\section{Conclusion and Future Work}

Extensive research has been done on improving the reagent scheme for direct/reverse flotation processing of calcite ores. This paper reviews the fundamental research and bench-scale flotation of calcite ore constituents. The advantages and disadvantages of anionic direct flotation, cationic reverse flotation, and mixed collector direct flotation are summarized in this paper. A large variety of reagents commonly used or in development for flotation, for example, collectors, and depressants are also described. The aim of this paper is to provide a well-detailed source for the current status of calcite ore flotation and thus provide a useful guide to its future development of flotation performance for calcite ore. 
Table 2 Overview of cationic reagents used for beneficiation of high-grade calcite ore

a. Calcite is a major constituent in the ore:

Author and year collecto

Srinivas et al. (2011)

Commercial amine collectors

(Chem-750 F or floatamine-D)
$\mathrm{pH} \quad$ Minerals/mineral system/ores
Natural Calcite, quartz, feldspar, pyroxene, and biotite

Results: The effect of feed flow rate, percent solids, froth depth, and wash water on the grade and recovery of the $\mathrm{CaCO}_{3}$ concentrate is studied in this paper. Recovery of $65-75 \%$, grade - 96-97\% was achieved using floatamine-D collector which was better than Chem-750 F in terms of solubility, selectivity, consumption, froth stability, and consistency.

Chernet et al. (2006)

\author{
Commercial amines (armoflote 18, armoflote 14, and \\ ethomen HT 60)
}

- $\quad$ Calcite, graphite

Results: Several batches of flotation tests were performed using a 4-1 flotation cell size with 35\% solid and conditioning time between 3 and 4 min. Brightness value: 92.3 from $83.7 \%$. High brightness with a good amount of calcite recovery was the result of this study.

$\begin{array}{llll}\text { Rao and Forssberg (1993) Stearylamine acetate } & 6 & \text { Calcite, silicates }\end{array}$

Results: Optimum brightness/grade/recovery was obtained only at about $\mathrm{pH} 6$.

Fang and Jun (2011) Alkyl amine salt (DAH), ether amine, quaternary amine salt Range of pH Phosphate, calcite, and silicates

Results: Alkyl amine salt is more effective for silica as compared with ether amine salt or quaternary ammonium salt. Approximately $23 \%$ increase in grade was observed by alkyl amine salt as compared with the other two.

Bunkholt and Kleiv (2014, 2015) Quaternary amine collector (Armofloat 18)

$8 \quad$ Calcite, sulphides, silicates

Results: The results of this study show that the removal of pyrrhotite and pyrite from a GCC (ground calcium carbonate) raw material using an amine collector can be achieved at $\mathrm{pH} 8.3$ and collector concentration around $200 \mathrm{~g} /$ tonne.

$\begin{array}{lll}\text { Dhar et al. (2019) } \quad \text { Duomeen collector } & 8.2 & \text { Calcite, sulphides, silicates }\end{array}$

Results: The results of this study show that the removal of pyrrhotite and pyrite from a GCC raw material using an diamine collector can be achieved at $\mathrm{pH}$ 8.2. The study found that the role of $\mathrm{pH}$ was extremely important as optimum metallurgical results were observed only above $\mathrm{pH} 6 / 7$.

b. Other studies, where calcite is present in moderate quantities, and their outcomes

(which provides important information about flotation and surface properties):

$\begin{array}{lll}\text { Author } & \text { Reagents } & \text { Minerals in the ore } \\ \text { Hanna (1975) } & \text { Quaternary amines (CTAB,CPB) } & \text { Phosphate ore-apatite, calcite; silicates }\end{array}$

Results: Quartz floated by quaternary ammonium salt from the quartz-calcite mixture, with primary amines selectivity, is low due to strong flocculated pulp, and flotation of calcite also occurred.
Abdel-Khalek (2000)
Custamine $6622-62 \mathrm{C}$ (cationic fatty amine acetate)
Calcite, silica, phosphate

(second stage)

Results: $0.5 \mathrm{~kg} /$ tonne of fatty amine was used in the second stage at neutral $\mathrm{pH}$ for best grade and recovery of calcite (silica removal).

Amines are the major cationic reagent used for reverse flotation of silicate/sulphide impurities. Pure mineral studies have shown that amines adsorb on the sulphide minerals via electrostatic interactions. Below pH 8, sulphide/silicate-amine interaction is due to $1: 1$ coordination, whereas above $\mathrm{pH} 8$, silicate/sulphide-amine interaction is attributed to $1: 2$ coordination. Primary and secondary amines also adsorb on calcite above $\mathrm{pH} 8$; thus, effective separation is possible at neutral or near-neutral $\mathrm{pH}$ values.
However, if calcite is present in the ore in minor quantities, it is usually floated out by using anionic collectors. Calcite displays good flotation performance in the presence of sodium oleate as the collector and a few studies were reported that used unconventional reagents. This article also presents various depressants and modifiers used for efficient separation of calcite from other calcium minerals. Extensive information regarding the interaction/adsorption mechanism of these anionic reagents has been reported in the past which is summarized in the text. 
Table 3 High-grade calcite ore flotation patents

\begin{tabular}{lll}
\hline Year and publication no. & Inventor & Collectors/ reagents used \\
\hline 1976 US3990966 A & Alan Stanley, Thomas F. Deems & $\begin{array}{r}\text { The group consisting of 1-hydroxyethyl-2-heptadecenyl } \\
\text { glyoxalidine and 1-hydroxyethyl-2-alkylimidazolines } \\
\text { and salt derivatives; the alkyl portion of the imidazoline } \\
\text { is the alkyl portion of a fatty acid }\end{array}$
\end{tabular}

Flotation of calcite-containing ores in the presence of a reagent, which separates mineral impurities (pyrite, quartz etc.) from calcite, increases brightness. The ore used in this study had a significant quantity of micaceous schist and silica gangue; xanthate flotation is undesirable. For efficient separation, flotation reagents, such as a combination of reagents having one fatty alkyl group and two polyoxyethylene groups attached to nitrogen, have been employed in this work. It was proven that using this combination of reagents, all of the insoluble impurities can be removed from the calcite ore.

1977 US4046678A Zajic, Kosaric

A microbial-based collector which is produced by growing culture or mixture of cultures selected from the genus Pseudomonas and/or the genus Alcaligenes, on a hydrocarbon substrate

In this work, the collector is prepared by injecting the culture system into an aqueous medium containing simple mineral salts and the hydrocarbon. $\mathrm{pH}$ for fermentation was maintained to be between $\mathrm{pH} 6$ and pH 10 and the process is aerobic, so the medium has an oxygen content of 0.1 to $30 \mathrm{mg} / \mathrm{L}$. The preferred temperature is $25-37^{\circ} \mathrm{C}$. Flotation of scheelite from calcite was efficient at $\mathrm{pH} 10-11.5$ using this microbial collector system.
1985, CA1187212A1
Delisle, Tremblay
Dimethyl dialkyl amine group (8 to 6 carbon atoms), alkyl dimethyl-benzyl (10-22 carbon atoms), bis-imidazoline (12 to 18 carbon atoms)

New flowsheet and reagent scheme for quartz flotation from calcite ores. The pulp density was $32 \%$ solid, and the flotation cell used in this work was the Denver Sub A model Dl. Calcite ore contained 7 0/0 insoluble and brightness is $85 \%$ before treatment. The pulp conditioning time was $<10$ min and flotation time was $<15 \mathrm{~min}$. The brightness of recoverable carbonates is $93-96 \%$ with optimum recovery.
1986/87 EP0216002A2
Wayne Merle Shiftlet
Acetate salt of a tall oil-based imidazoline to the slurry; a non-polar hydrocarbon oil

Beneficiating natural calcite ore including the steps of subjecting an aqueous slurry of ground ore to a froth-flotation cell. The reagent scheme is new: initially adding an acetate salt of a tall oil-based imidazoline to the aqueous slurry of ground calcite ore, and thence mixing a non-polar hydrocarbon oil into the imidazoline-treated aqueous slurry of micronised calcite ore. It is followed by stirring the treated (calcite) slurry to efficiently condition by the non-polar hydrocarbon oil. Conditions: solid content - 45-50\%; particle size (90-100\% — passing through 100 mesh). Calcite recovery > $90 \%$ was achieved.

\author{
1988, EP0291271A1 \\ Christopher Robin Langdon Golley (ECC \\ International Limited)
}
Amine or quaternary ammonium compound containing at least one long-chain alkyl group having from 10 to 24 carbon atoms

Natural calcite ore was purified using 60-80 weight (wt) \% feed. Conditioning time was 5-90 min. Amount of collector used is preferably 100-1000 ppm. Hydrogen peroxide (oxidizing agent) was added along with the frother during flotation, which has no effects on the metallurgical results (proven in the work). The brightness and grade were optimum.

\section{DE2900620C2 Herbert Ike Wrens Ga. Us Lewis, Anthony David Sandersville Ga. US Macconell William M. St. Austell Cornwall Gb Price}

Salt of a 1-hydroxymethyl-2-alkylimidazoline in which the alkyl part of the imidazoline is the alkyl part of a fatty acid having 10 to 20 carbon atoms of its carbon chain and that the flotation agent is used in conjunction with an enhancer comprising one or more aliphatic hydrocarbons having a carbon chain length of 10 to 20 carbon atoms

This process was developed for increasing brightness to 3-4\% by removing the impurity minerals. The main finding of this work was excellent improvements in results (both brightness and acid-insoluble) were achieved by the combined use of such salt derivatives with the aliphatic hydrocarbons. 
Table 3 (continued)

\begin{tabular}{|c|c|c|}
\hline Year and publication no. & Inventor & Collectors/ reagents used \\
\hline $\begin{array}{c}1990 \text { US4982649A } \\
\text { US4995965A }\end{array}$ & Mehaffey and Newman & $\begin{array}{l}\text { Organo-nitrogen-compounds including propoxylated } \\
\text { quaternary ammonium compounds, unsymmetrical } \\
\text { dialkyl dimethyl quaternary ammonium compounds } \\
\text { and dialkyl hexa-hydropyrimidine compounds }\end{array}$ \\
\hline
\end{tabular}

This work presents a process for the purification of a calcium carbonate ore containing silicate impurities. The process consists of grinding and preparation of an aqueous slurry of the ore, adding an effective amount of collector to the slurry ( 0.1 to about 0.5 pounds per tonne of ore) and separating the impurities from the slurry by flotation. The yield was close to $90 \%$ and an acid-insoluble was approximately $0.5 \%$. Thus, the process achieves high yields and low acid-insoluble content of the calcium carbonate product by employing the novel collector scheme.

Hancock and Wang, Cytec
Tech group

Alkoxylated $\mathrm{C}_{8}-\mathrm{C}_{24}$ alkyl guanidine containing 1-10
alkoxy groups, an alkoxylated $\mathrm{C}_{8}-\mathrm{C}_{24}$ alkyl fatty
amine-containing $1-6$ alkoxy groups and mixtures

The work presents a novel reagent system for reverse flotation of silicates, pyrite etc. The required calcite grade, recovery, and brightness were obtained.

$\begin{array}{cl}\begin{array}{c}\text { 1998, US5720873A, } 1994 \quad \text { Klingberg, Olsson } \\ \text { WO1994026419A1 }\end{array} & \begin{array}{l}\text { Methyl-bis(2-hydroxypropyl)-cocoalkyl ammonium methyl } \\ \text { sulphate; dimethyl didecyl ammonium chloride; } \\ \text { dimethyl-di(2-ethyl-hexyl)-ammonium chloride (A); } \\ \text { dimethyl-(2-ethyl-hexyl)-cocoalkyl ammonium chloride; } \\ \text { dicocoalkyl dimethvi ammonium chloride; and n-tallow } \\ \text { alkyl-1,3-diamino propane diacetate (B) }\end{array}\end{array}$

A method of cleaning calcite ore containing silicate impurities by the froth-flotation process in the presence of a cationic amine collector. The collectors according to the current study were added individually, but are preferred to be added together. The total content of the two reagents (A and B) were approximately 50-2000 and 200-1000 g/tonne of ore to be floated, respectively. The calcite yield was calculated as $0.8 \%$ acid-insoluble matter.

\author{
2008, EP1944088 A1 Tavakkoli, Dipling, Mangelberger, \\ WO2008084391A1
}

Quaternary imidazoline methosulphate compound has a side chain which is saturated or not, the said side chain containing from 8 to 22 , preferably from 12 to 20 , very preferably from 16 to 18 carbon atoms.

One flotation step, capable of removing impurities from natural calcite ores by quaternary imidazoline methosulphate compound. The most favourable flotation time was $20 \mathrm{~min}, \mathrm{pH}$ was 7-8.5, and 400-600 ppm collector concentration. A calcite recovery of 90-98\% was recorded.
2011 EP2547453A1
Patrick, Buri, Rentsch, and Sötemann
A hydrophobically modified polyalkyleneimine

Process of separation of silicates and alkaline earth carbonates from calcite prior to modification; the polyalkyleneimine has minimum 3 alkyleneimine repeating units and a molecular weight of between 140,000 and 100,000 $\mathrm{g} / \mathrm{mol}$. The modification of the polyalkyleneimine leads to an increase in the atomic $\mathrm{C}$ amount, relative to the unmodified polyalkyleneimine. This reagent scheme increases selectivity in flotation and minimizes chemical loss.

$\begin{array}{lll}\text { 2013, US8353405 B2 } 2007 & \text { Klingberg, Henriksson } & \begin{array}{c}\text { Fatty tri-lower-alkyl quaternary ammonium compounds, } \\ \text { fatty di-lower-alkyl benzyl quaternary ammonium }\end{array} \\ \text { WO2007122148A1 2009 } & \text { compounds, fatty lower-alkyl di-benzyl quaternary } \\ \text { US20090206010A1 } & \text { ammonium compounds, di-fatty di-lower-alkyl quats, di-fatty } \\ & \text { lower-alkyl benzyl quats, and fatty bis-imidazoline quats }\end{array}$

The combination of different quats as collectors was found to result in a synergetic performance. When a total of $440 \mathrm{~g} /$ tonne collector mixture was used, $95 \%$ brightness was obtained.

2013, CN101583431 Omya Development AG
Quaternary imidazolone methosulphate compound;quaternary imidazolium gun methyl-2-methyl sulphates reduced to 3-oleyl oleate-amido ethyl-imidazol-gun methyl sulphate.

Purification of calcite in one flotation step by using quaternary imidazolone methosulphate compound. The flotation process was performed in Outokumpu laboratory, in a mechanical bench-scale flotation cell of 41 , under the agitation of $1500 \mathrm{rpm}$ and at a pulp temperature of $20{ }^{\circ} \mathrm{C}$. The solid content was of $30 \%$ by weight. It contained $7.2 \%$ by weight of impurities as characterized by hydrochloric acid-insoluble residue. The conditioning time period was 2 min under the agitation of $1500 \mathrm{rpm}$. 98\% recovery was observed. 
Table 3 (continued)

\begin{tabular}{lll}
\hline Year and publication no. & Inventor & Collectors/ reagents used \\
\hline $\begin{array}{c}2014 \text { EP2700680 A1 2014 } \\
\text { WO2014029634 A1 }\end{array}$ & Sötemann Jörg & Amines (synthesized by the company)
\end{tabular}

White pigment substance and removal of its impurities; novel reagent system was used. The experiments were conducted in Outotech laboratory flotation cell. Pulp density (33\% dry weight), approximately $80 \%$ reagent was added at the beginning of flotation and 2 min of conditioning time was used.

\author{
2013 US8381915 B2 Tavakkoli, Mangelberger, Maier, Buri
}
Quaternary imidazoline methosulphate compound; 1-methyl-2-noroleyl-3-oleic acid-amidoethylimidazolium-methylsulphate

Purification of calcium carbonate in one step by quaternary imidazoline methosulphate compound. Approximately, 90-98\% of recovery was noticed using this collector.
1993 US5261539A
Hancock M and Wang J
A mixture of an alkoxylated alkyl guanidine and an alkoxylated alkyl amine

Better techniques to improve the brightness of calcite ore, removal of silicate, pyrite, and other impurities. Flotation testing was performed in a bench Denver flotation machine at $800 \mathrm{rpm}$ and in each batch; $1-\mathrm{kg}$ feed was used. The slurry \% solids are $31 \%-600-\mathrm{g}$ dry flotation feed solids and $1300 \mathrm{~mL}$ of tap water. The slurry is conditioned for $2 \mathrm{~min}$ before flotation reagent addition and for $2 \mathrm{~min}$ after flotation collector addition at the desired dosage. The air is turned on and flotation is conducted for $7 \mathrm{~min}$ The metallurgical results and brightness matched to the required standards.

\title{
2007, WO2008089906 A1 Joaquin Bigorra L, losasDietger, KöpplSimone, Esterquats \\ Hoffmann-Dörrklaus Hinrichs
}

Flotation of non-sulphidic minerals or ores. The novelty is the use of the polymeric collector esterquats, obtainable by reacting alkanolamines with a mixture of monocarboxylic acids and dicarboxylic acids and quaternising the resulting esters in a known manner, optionally after alkoxylation. The metallurgical results were optimum and the collector is non-toxic.
2014 EP2700680A1
Jörg Sötemann, Andreas Maier
Quaternary amine derivative

Flotation was performed to achieve high-grade calcite. The results confirm that the collector agents used in this study indicate higher stability in comparison with prior art collector agents. Additionally, the metallurgical results also improved relative to the other reagents used in industries.
2016 EP3208314A1
Jörg Sötemann
Ethoxylated tallow diamine

Used for producing calcium carbonate for GCC feed. The criteria for determination of purity are carbon fraction determination (\% by weight), brightness analysis, and particle size analysis. All the results showed improvement in the brightness and quality of the GCC feedstock.
2011, WO2011147855A2
Natalija Gorochovceva, Anders Klingberg
Polymeric quaternary ester

Flotation tests were performed in a laboratory batch flotation machine with a $1.5-\mathrm{L}$ cell. $0.5-\mathrm{kg}$ ore sample was added to the cell, tap water was added to $1.4 \mathrm{~L}$ volume, and agitation with $900 \mathrm{rpm}$ was used throughout the tests. The tests were performed at a $\mathrm{pH}$ of 8.5 (natural) and at ambient temperature, which was about $20^{\circ} \mathrm{C}$. Results were measured in terms of calcite recovery and acid-insoluble data. It was found that all the results were better than previously used quaternary ester collectors.
2020, EP3444036A1
Jörg Sötemann, David Gilbert, Jörg
Maier, Tomi Matti Juhani Niitti
Novel amine collector

Purification of wollastonite, kaolin, kaolinitic clay, montmorillonite, talc, diatomaceous earth, sepiolite, and mixtures of silicates from calcite. The brightness of the calcite was highly improved using the novel amine collector.
2017, CN111032225A Jorge Zetman, Jorg Meyer, David Gilbert, Tommy Novel quaternary imidazoline collector Marty, and Yohani Nity

Purification of calcite is more efficient; the aforementioned collector binds to the surface of the impurity more efficiently than to the surface of the calcite. Quality parameters were characterized by high brightness and low yellowness index. 
For the beneficiation of high-grade calcite ores with sulphides or silicates as impurities, reverse flotation has an edge over the normal flotation technique in industries. The reason is that the directly floated calcite is usually influenced by the reagent employed for flotation. However, these alterations may be undesirable in the end-use of the paper, plastics, paint, and coating industries. Thus, the major patents filed in recent or past years are based on the reverse flotation of calcite ore. However, few studies were conducted in the past on the interaction mechanism of these tailor-made reagents or the novel reagents with calcite/impurity minerals. In conclusion, it can be stated that there is considerable scope for studying the detailed interaction or adsorption mechanism of quaternary amines/esterquats/novel biosurfactants with calcite and the other gangue minerals.

Acknowledgements Open Access funding provided by NTNU Norwegian University of Science and Technology (incl St. Olavs Hospital - Trondheim University Hospital).

Open Access This article is licensed under a Creative Commons Attribution 4.0 International License, which permits use, sharing, adaptation, distribution and reproduction in any medium or format, as long as you give appropriate credit to the original author(s) and the source, provide a link to the Creative Commons licence, and indicate if changes were made. The images or other third party material in this article are included in the article's Creative Commons licence, unless indicated otherwise in a credit line to the material. If material is not included in the article's Creative Commons licence and your intended use is not permitted by statutory regulation or exceeds the permitted use, you will need to obtain permission directly from the copyright holder. To view a copy of this licence, visit http://creativecommons.org/licenses/by/4.0/.

\section{References}

Abdel-Khalek N (2000) Evaluation of flotation strategies for sedimentary phosphates with siliceous and carbonates gangues. Miner Eng 13(7): 789-793

Abouzeid N, Elgillani DA (2009) Upgrading of calcareous phosphate ores by flotation: effect of ore characteristics. Int J Miner Process 90(1):81-89

Amankonah JO, Somasundaran P (1985) Effects of dissolved mineral species on the electrokinetic behavior of calcite and apatite. Colloids Surf A Physicochem Eng Asp 15:335-353

Amankonah JO, Somasundaran P, Anathapadmanabhan KP (1985) Effect of dissolved mineral species on the dissolution precipitation characteristics of calcite and apatite. Colloids Surf A Physicochem Eng Asp 15:295-307

Ananthapadmanabhan KP, Sumasundaran P (1984) The role of dissolved mineral species in calcite-apatite flotation. Miner Metall Process 1(1):36-42

Andersen JB, El-Mofty SE, Somasundaran S (1991) Using electrophoresis for determining the mechanism of amine, sulfate and oleate adsorption in calcite. Colloids Surf A Physicochem Eng Asp 55:365368

Antti BM, Forssberg KSE (1989) Pulp chemistry in industrial mineral flotation. Studies of surface complex on calcite and apatite surfaces using FTIR spectroscopy. Miner Eng 2(2):217-227
Arnold R, Brownbill EE, Ihle SW (1978) Hallimond tube flotation of scheelite and calcite with amines. Int J Miner Process 5:143-152

Atademir MR, Kitchener JA and Shergold HL (1981) The surface chemistry and flotation of scheelite, II. Flotation "collectors". Int J Miner Process 8: 9-16

Atak S, Gurkan V, Yafawi A (1986) Effects of various fatty acids on separation of scheelite from calcite. In: Aytekin Y (ed) 1st Int. Miner. Process. Syrup, Izmir, pp 94-103

Baldauf H, Schubert H, Kramer H (1986) N-Acylamino carboxylic acids, collectors for the flotation separation of fluorite and calcite. Aufbereitungs-technik 5:235-241

Bigorra, Joaquin, Dietger Losas, Simone Köppl Hoffmann-Dörrklaus Hinrichs (2007) Process for the flotation of non-sulfidic minerals and ores, Patent no.- WO2008089906A1

Bulatovic SM (2007) Flotation of Lead-Zinc Ores. In: Handbook of flotation reagents: chemistry, theory and practice, vol 1. Elsevier, Amsterdam, pp 323-366

Bunkholt I, Kleiv RA (2014) Pyrrhotite oxidation and its influence on alkaline amine flotation. Miner Eng vol 71

Bunkholt I, Kleiv RA (2015) Flotation of pyrrhotite and pyrite in saturated $\mathrm{CaCO}_{3}$ solution using a quaternary amine collector. Miner Eng 70:55-63

Cases JM (1979) Adsorption des tensio-actifs a interface solide-liquide: thermodynamique et influence de L'heterogeneite des adsorbants. Bull Mineral 102:684-707

Cases JM (1989) Thermodynamics of the adsorption of surfactants, in F.I.A. (ed.) Kurzjassungen der Vortrage und Posterbiertrage-2. Internationale Fachtagung Fortschritte in Theorie und Praxis der Aujbereitungstechnik, Freiberg, pp. 341-356

Cases JM, Levitz P, Poirier JE, Van Damme H (1986) Adsorption of ionic and nonionic surfactants on mineral solids from aqueous solutions. In: Somasundaran P (ed) Advances in mineral processing. SME Publication, Littleton, Col., pp 171-186

Castro H'i B'd d F, Calero de Hoces M (1993) Influence of quebracho and sodium silicate in flotation of celestite and calcite with sodium oleate. Int J Miner Process 37:283-298

Castro H'i B'd d F, Calero de Hoces M, Ga'lvez Borrego A (1996) The effect of $\mathrm{pH}$ modifier on the flotation of celestite with sodium oleate and quebracho. Chem Eng Sci 51:4289-4294

Chang LLY, Howie RA, \& Zussman J (1996) Calcite, p 101-135. In: Sulphates, carbonates, phosphates and halides. Deer, Howie and Zussman. Rock-forming minerals, Vol. 5B: non-silicates. Second edition, pp. 383

Chernet T, Wiik M, Lehto H, Reinikainen J, Vuori J (2006) The effect of micro-grinding and micro-graphite flotation to upgrade the quality of calcite concentrate, with reference to Kurikka calcite marble deposit, Finland. Miner Eng 19(4):372-375

Chernyshova IV, Ponnurangam S, Somasundaran P (2011) Adsorption of fatty acids on iron (Hydr)oxides from aqueous solutions. Langmuir 27:10007-10018

Christopher Robin Langdon Golley, (1988) EP0291271A1

Dawoud AM, Vinogradov J, Jackson MD (2017) Zeta potential of artificial and natural calcite in aqueous solution. Adv Colloid Interf Sci 240:60-76

Delisle Tremblay (1985) patent No. CA1187212A1

Deng L, Zhao G, Zhong H, Wang S, Liu G (2016) Investigation on the selectivity of $\mathrm{N}$-((hydroxyamino)-alkyl) alkylamide surfactants for scheelite/calcite flotation separation. J Ind Eng Chem 33:131-141

Dhar P, Thornhill M, Kota HR (2019) Purification of high-grade calcite ore by flotation with alkyl diamines. Min Metall Explor 36:463-474

Dietrich RV (2013) Calcite, Encyclopædia Britannica (Website)

Douglas H, Walker R (1950) The electrokinetic behaviour of Iceland spar against aqueous electrolyte solutions. J Chem Soc Faraday Trans 1950(46):559-568

Elgillani DE (1978/1979) On the problem of calcite separation from apatite. Bulletin Fac. Engng. Cairo University, p. 237 
Fang, G \& Jun. L (2011). Selective separation of silica from a siliceouscalcareous phosphate rock. Min Sci Technol (China), 21(1), 135139

Feng B, Luo X, , Luo Xianping, Jinqing, W \& Pengcheng W. (2015). The flotation separation of scheelite from calcite using acidified sodium silicate as depressant. Miner Eng, 80, 45-49

Filippov LO, Filippova IV, (2006) Synergistic effects in mix collector systems for non-sulfide mineral flotation. In: Onal, G., et al., (Eds.), Proc. of XXIII Int. Min Proc. Congress, Istanbul, Turkey, 3-8 September 2006, pp. 631-634

Filippov LO, Duverger A, Filippova IV, Kasaini H, Thiry J (2012) Selective flotation of silicates and Ca-bearing minerals: the role of non-ionic reagent on cationic flotation. Miner Eng 36-38:314-323

Filippova IV, Filippov LO, Duverger A, Severov J (2014) Synergetic effect of a mixture of anionic and nonionic reagents: Ca mineral contrast separation by flotation at neutral $\mathrm{pH}$. Miner Eng 66-68: $135-144$

Finkelstein NP (1998) Review of interactions in flotation of sparingly soluble calcium minerals with anionic collectors. Trans IMM Sec C, 98,157

Fu E, Somasundaran P (1986) Alizarinred S as a flotation modifying agent in calcite-apatite systems. Int J Miner Process 18:287-296

Fuerstenau MC, Gutierrez G, and Elgillant DA (1968) Trans Amer lnst Min Eng. 241, 319

Gallios GP, Matis KA (1989) Flotability of magnesium carbonates by sodium oleate in the presence of modifiers. Sep Sci Technol 24(182):129-143

Gang L, Weng, Wei DZ, Wang BY, Fang P, Wang XH, Cui BY (2009) A new collector used for flotation of oxide minerals. Trans Nonferrous Metals Soc China 19(5):1326-1330

Gao B, Sun C, Hu Y (2015) Selective flotation of scheelite from calcite and fluorite using a collector mixture. Miner Eng 72:23-26

Gaudin AM, Fuerstenau DW (1955) Quartz flotation with cationic collectors. Trans AIME 202:441-501

Gibson C, Kelebek S, Aghamirian M, Yu B (2015) Flotation of pyrochlore from low grade carbonatite gravity tailings with benzohydroxamic acid. Miner Eng 71:97-104

Giesekke EW, Harris PJ (1994) The role of polyoxyethylene alkyl ethers in apatite flotation at Foskor, Phalaborwa (South Africa). Miner Eng 7(11):1345-1361

Gorochovceva Natalija and Klingberg Anders (2011) Quaternary ammonium compounds and their use as collectors in froth flotation processes, Patent no. WO2011147855A2

Goujon C, Mutaftschie V (1976) On the adsorption of Ndodecylammonium chloride on the surface of synthetic calcite. $\mathrm{J}$ Colloid Interface Sci 56(3):587-595

Gutierrez C (1979) Bifluence of calcium ion and quebracho in the oleate flotation of fluorite and calcite. Trans AIME 2QQ, 1918-1924

Han HS, Liu WL, Hu YH et al Rare Met (2017) A novel flotation scheme: selective flotation of tungsten minerals from calcium minerals using $\mathrm{Pb}$-BHA complexes in Shizhuyuan. 1001-0521

Hancock M and Wang J (1993) US5261539A

Hancock M and Wang J (1994), EP591633A1

Hanna SH (1975) The role of cationic surfactants in the selective flotation of phosphate ore constituents. Powder Technol 12:57-64 @ Elsevier Sequoia S.A., Lausanne - Printed in The Netherlands

Harwell JH, Schechter R, Wade WH (1985) Recent developments in the theory of surfactant adsorption on oxides. In: Cases JM (ed) Solidliquid interactions in porous media. Technip, Paris, pp 371-409

Herbert Ike Wrens Ga (1988) US Lewis, Anthony, David Sanderville Ga. US Macconell William M. St. Austell Cornwall GB Price. DE2900620C2

$\mathrm{Hu} \mathrm{Y}, \mathrm{Xu} \mathrm{Z}$ (2003) Interactions of amphoteric amino phosphoric acids with calcium-containing minerals and selective flotation. Int J Miner Process 72(1):87-94
Hu YH, Yang F, Sun W (2011) The flotation separation of scheelite from calcite using a quaternary ammonium salt as collector. Miner Eng 24(1):82-84

Irannajad M, Ejtemaei M, Gharabaghi M (2009) The effect of reagents on selective flotation of smithsonite calcite quartz. Miner Eng 22(9/10): $766 \mathrm{e} 71$

Iskra J, Gutierrez C, and Kitchener JA (1973) Influence of quebracho on the flotation offluorite, calcite, hematite and quartz with oleate as collector. Trans. IMM 82. C73-C78. 37

Jena MS, Sahu P, Dash P, Mohanty JK (2013) Beneficiation of limestone plant rejects for value addition. J Hazard Mater 262:218-227

Jung RF (1976) Oleic acid adsorption at the goethite-water interface, M.Sc. Thesis, Univ. of Melbourne

Jung RF, Lames RO, Healy TW (1988) A multiple equilibria model of the 354 adsorption of oleate aqueous species at the goethite-water interface. J Colloid Interface Sci 122:544-549

Karlkvist T, Patra A, Rao KH, Bordes R, Holmberg K (2015) Flotation selectivity of novel alkyl dicarboxylate reagents for apatite-calcite separation. J Colloid Interface Sci 445:40-47

Kellar JJ, Cross WM, Miller JD (1990) In-situ internal spectroscopy for the study of surfactant adsorption reactions using reactive internal reflection elements. Sep Sci Technol 25

Klingberg A, Olsson L (1998) US5720873A

Klingberg A, Henriksson E (2013) US8353405 B2; (2007) WO2007122148A1; (2009) US20090206010A1

Kongolo MB, de Donato P, Drouet B, Barrès O (2004) The comparison between amine thioacetate and amyl xanthate collector performances for pyrite flotation and its application to tailings desulphurization. Miner Eng 17(2004):505-515

Kulkarni RD (1975) "Flotation properties of hematite-oleate system and their dependence on interfacial adsorption", D. Eng. Sci. Thesis, Columbia University, New York

Kydros K, Matis K, Stalidis G (1993) Cationic flotation of pyrites. J Colloid Interface Sci 155:409-414

Laskowski JS, Liu Q, Bolin NJ (1991) Polysaccharides in flotation of sulphides. Part I. Adsorption of polysaccharides onto mineral surfaces. Int J Miner Process 33(1):223-234

Leja J (1982) Surface chemistry in froth flotation. Plenum, New York

Marinakis KI, Shergold HL (1985) The mechanism of fatty acid and adsorption in the presence of fluorite, calcite and barite. Int $\mathrm{J}$ Miner Process 14(3):161-176

Martı'nez-Lue'vanos A, Uribe-Salas A, Nava-Alonso FC, Lo'pezValdivieso A (2000) The role of quebracho and sodium silicate modifiers on the flotation of celestite and calcite with sodium dodecyl sulfonate. Afinidad LVII (485), 357-362

Mehaffey Newman (1990) US 4982649A

Mehdilo A, Irannajad M (2015) Evaluation of pyrolusite flotation behavior using a cationic collector. J Min Sci 50(5):982-993

Mishra S (1979) The electrokinetic properties and flotation behaviour of apatite and calcite in the presence of dodecylamine chloride. Int $\mathrm{J}$ Miner Process 6(2):119-132

Mishra SK (1982) Electrokinetic properties and flotation behaviour of apatite and calcite in the presence of sodium oleate and sodium metasilicate. Int J Miner Process 9:59-73 1982

Mishra RK, Chander S, Fuerstenau DW (1980) Effect of ionic surfactants on the electrophoretic mobility of hydroxyapatite. Colloids Surf A Physicochem Eng Asp 1:105-119

Morozov VV, Baldauf H, Schubert H (1992) On the role of the ion composition of the aqueous phase in the flotation of fluorite and calcite. Int J Miner Process 35:177-189

Moulin P, Roques H (2003) Zeta potential measurement of calcium carbonate. J Colloid Interface Sci 261(1):115-126

Nagaraj DR, Farinato RS (2016) Evolution of flotation chemistry and chemicals: a century of innovations and the lingering challenges. Miner Eng 96(2016):2-14 
Nanthakumar B, Kelebek S (2007) Stagewise analysis of flotation by factorial design approach with an application to the flotation of oxidized pentlandite and pyrrhotite. Int J Miner Process 84(1): 192-206

Ni X, Liu Q (2013) Adsorption behaviour of sodium hexametaphosphate on pyrochlore and calcite. Can Metall Q 52(4):473-478. https://doi. org/10.1179/1879139513Y.0000000088

O'Connor CT, Dunne RC, Martalas A (1987) The adsorption of oleate and the guar-based gum, acrol LG-21, onto apatite and calcite. Colloids Surf A Physicochem Eng Asp 27:357-365

OMYA Development AG (2013) CN101583431

Orthgiess, Dobiáš (1994) Complexing agents as modifiers in mineral flotation-mechanism studies. Colloids Surf A Physicochem Eng Asp 83(2):129-141

Ozcan O, Bulutcu AN, Sayan P, Recepoglu O (1994) Scheelite flotation: a new scheme using oleoyl sarcosine as collector and alkyl oxine as modifier. Int J Miner Process 42(1):111-120

Patrick A, Gane C, Buri Matthias, Rentsch Samuel, and Sötemann Jörg (2011) EP2547453A1

Peck AS (1963) Infrared studies of oleic acid and sodium oleate adsorption on fluorite, baryte and calcite, Rep. Invest. U.S. Bur. Mines 6202, p. 16

Peck AS, and Wadsworth ME (1964) Infrared study of the depression effect offluoride, sulphate, and chloride on chemisorption of oleate on fluorite and baryte, in Proceedings $7^{\text {th }}$ International Mineral Processing Congress, Gordon and Breach, New York, vol. I, pp. 259-267

Pekkala Y (1985) Petrography, geochemistry and mineralogy of the Precambrian metasedimentary carbonate rocks in North Kuusamo, Finland. Geological Survey Finland Bulletin 332, 62

Pradip, Fuerstenau DW (1985) The adsorption of hydroxamate on semisoluble minerals. Part I: adsorption on barite, calcite and bastnaesite. Colloids Surf A Physicochem Eng Asp 8:103-119

Prasad, M, Majmudar AK, Rao GM and Rao TC (1994) Flotation studies on a low-grade cherty-calcareous rock phosphate ore from Jhabua, in Proceedings Minerals and Metallurgical Processing, pp 92-96

PubChem Database (1977) Calcium carbonate, CID $=10112$, National Center for Biotechnology Information

Quast K (2016) Literature review on the interaction of oleate with nonsulphide minerals using zeta potential. Miner Eng 94:10-20

Rao Hanumantha (1992). Interactions of anionic collectors in flotation of semi-soluble salt minerals (NatoConference)

Rao KH, Forssberg KSE (1991c) Mechanism of oleate interaction on salttype minerals. Part III. Adsorption, zeta potential and diffuse reflectance FT-IR studies of scheelite in the presence of sodium oleate. Colloids Surf A Physicochem Eng Asp 54:161-187

Rao Hanumantha and Forssberg KSE. Purification of Gåsgruvan calcite by anionic and cationic flotation. In: Proc. XVIIIth Int. Miner. Process. Congr., May 23-28, 1993, Sydney, Aust. Inst. Min. Metal., Publ. Series No 3/93, Vol. 4, pp. 1037-1043

Rao D, Vaman Narayanan MK, Nayak UB, Ananthapadmanabhan K, Somasundaran P (1985) Flotation of calcareous Mussorie phosphate ore. Int J Miner Process 14:57-66

Rao KH, Antti B-M, Forssberg E (1989) Mechanism of oleate interaction on salt-type minerals part I. Adsorption and electrokinetic studies of calcite in the presence of sodium oleate and sodium metasilicate. Colloids Surf A Physicochem Eng Asp 34:227-239

Rao KH, Cases JM, Donato D, Forssberg E (1991a) Mechanism of oleate interaction on salt-type minerals: IV. Adsorption, electrokinetic, and diffuse reflectance FT-IR studies of natural fluorite in the presence of sodium oleate. J Colloid Interface Sci 145(2):314-329

Rao KH, Cases JM, de Donato P, Forssberg KSE (1991b) Mechanism of oleate interaction on salt-type minerals, IV. Adsorption, electrokinetic and diffuse reflectance FT-IR studies of natural fluorite in the presence of sodium oleate. J Colloid Interface Sci 145(2):314-329
Ribeiro C, Monte S, Mothé, Lima (2003) Cashew gum: a new depressor for limestone in the phosphate minerals flotation. Miner Eng 16(9): 873-875

Sadowski, Z. (1990) The effect of dispersant reagents on the sodium oleate adsorption at the salt minerals-water interface, 8th International. Symposium of Surfactants in Solution, Gainesville, USA, June 10-15

Santos EP Achilles JB Dutra J, Oliveira F (2015) The effect of jojoba oil on the surface properties of calcite and apatite aiming at their selective flotation. Int J Miner Process 143:34-38

Sayan P. (2005). Effect of sodium oleate on the agglomeration of calcium carbonate Cryst Res Technol, 40 (3) (2005), pp. 226-232

Schubert H, Baldauf H, Kramer W, Schoenherr J (1990) Further development of fluorite flotation from ores containing higher calcite contents with oleoylsarcosine as collector. Int J Miner Process 30:185193

Scott J, Smith RW (1991) Diamine flotation of quartz. Miner Eng 4:141150

Shi Q, Zhang G, Feng Q, Deng H (2012) Effect of solution chemistry on the flotation system of smithsonite and calcite. Int J Miner Process 119(2013):34-39

Sirkeci AA (2000) Electrokinetic properties of pyrite, arsenopyrite and quartz in the absence and presence of cationic collectors and their flotation behavior. Miner Eng 13(10-11):1037-1048

Sis H, Chander S (2003) Adsorption and contact angle of single and binary mixtures of surfactants on apatite. Miner Eng 16(9):839-848

Smith R, Shonnard D (1986) Electrokinetic study of the role of modifying agents in flotation of salt-type minerals. AICHE J 32(5):865-868

Somasundaran, P. (1969). Adsorption of starch and oleate and interactions between them on calcite in aqueous solutions, J Colloid Interface Sci. n(4). 557-565. 39

Somasundaran P (1975) The role of ionomolecular surfactant complexes in flotation. Int J Miner Process 3:35-40

Somasundaran P, Amankonah JO, Ananthapadmabhan K (1985) Mineral-solution equilibria in sparingly soluble mineral systems. Colloids Surf A Physicochem Eng Asp 15:309-333

Somasundaran P, Amankonah JO, Ananthapadmabhan KP (1996) Colloids Surf A Physicochem Eng Asp 15:309

Sötemann Jorg (2014) EP2700680 A1 (2014) WO2104029634 A1

Sötemann Jörg (2016) Process for manufacturing white pigment containing products, Patent no. - EP3208314A1

Sötemann Jörg, Maier, Andreas Jörg (2014) Process for manufacturing white pigment containing products, Patent No.- EP2700680A1

Sötemann Jörg, Gilbert David, Maier Jörg, Matti Tomi, Niitti Juhani (2020) Indirect flotation process for manufacturing white pigment containing products, Patent No.- EP3444036A1

Srinivas Rao D, Vijayakumar SR, Bhaskar R, Prabhakar S (2011) Beneficiation of a low grade limestone sample. Min Sci Technol (China) 21(5):631-636

Stanley A, Deems TF (1976) US Patent no. US3990966

Szezypa J, Chibowski St, and Kuspit K (1979) Mechanism of adsorption of sodium laurate by calcium carbonate, Trans. IMM, March, CIIC13

Tavakkoli B, Dipling D, Mangelberger M, Maier J, Buri M, Elrejtes (2008). EP1944088 A1, WO2008084391 A1

Tavakkoli B, Mangelberger T, Maier J, Buri M (2013) US8381915 B2

Valdivieso LA, Robledo C, Uribe-Salas A (2000) Flotation of celestite with the anionic collector sodium dodecyl sulfate. Effect of carbonate ions. Int J Miner Process 60(2):79-90

Valdiviezo LA, Oliveira F (1993) Synergism in aqueous solutions of surfactant mixtures and its effect on the hydrophobicity of mineral surfaces. Miner Eng 6(6):655-661

Watne T (2001) Geological variations in marble deposits. Implications for the mining of raw material for ground calcium carbonate slurry products. PhD Thesis, Department of Geology and Mineral 
Resources Engineering, Norwegian University of Science and Technology (ISBN 82-7984-185-7)

Wayne Merle Shiftlet (1986) Process for beneficiating natural calcite ores, EP0216002A2

Wu XQ, Zhu JG (2006) Selective flotation of cassiterite with benzohydroxamic acid. Miner Eng 19(14):1410-1417

Yongxin L, Changgen L (1983) Selective flotation of scheelite from calcium minerals with sodium oleate as a collector and phosphates as modifiers. I. Selective flotation of scheelite. Int J Miner Process 10:205-218

Young MF and Miller JD Fuerstenau M, Jameson G, \& Yoon R (2007) Froth flotation: a century of innovation. Littleton, Colo.: Society for Mining, Metallurgy, and Exploration

Yu B, Che X, Zheng Q (2014) Flotation of ultra-fine rare-earth minerals with selective flocculant PDHA. Miner Eng 2014(60):23-25
Zajic Kosaric (1977) US Patent No. US4046678A

Zhang P, Yu Y, Hanson H, Snow R (1999) Fundamentals and practical implications of the role of polymers in separating silica from phosphate beneficiation phosphates. Adv Res Pract:41-52

Zetman Jorge, Meyer Jorg, Gilbert David, Marty Tommy and Nity Yohani (2017) CN111032225A

Zhou Q, Lu S (1992) Acidized sodium silicate-an effective modifier in fluorite flotation. Miner Eng 5(3):435-444

Zimmels Y, Lin IJ (1974) Stepwise association properties of some surfactant aqueous solutions. Colloid Polym Sci 252:594-612

Zimmels Y, Lin IJ, Friend JP (1975) The relation between stepwise bulk association and interfacial phenomena for some aqueous surfactant solutions. Colloid Polym Sci 355:253,404-253,421 